\title{
Review \\ Intercellular Communication in the Brain through Tunneling Nanotubes
}

\author{
Khattar E. Khattar ${ }^{1,+}$, Janice Safi ${ }^{1,+}$, Anne-Marie Rodriguez ${ }^{2}$ iD and Marie-Luce Vignais ${ }^{1, *(D)}$ \\ 1 Institut de Génomique Fonctionnelle, University Montpellier, CNRS, INSERM, Montpellier, France; \\ khattar.khattar@igf.cnrs.fr (K.E.K.); janice.safi@igf.cnrs.fr (J.S.) \\ 2 University Paris Est Créteil, INSERM, IMRB, Créteil, France; anne-marie.rodriguez@inserm.fr \\ * Correspondence: marie-luce.vignais@igf.cnrs.fr \\ + Co-first authors.
}

Citation: Khattar, K.E.; Safi, J.; Rodriguez, A.-M.; Vignais, M.-L. Intercellular Communication in the Brain through Tunneling Nanotubes. Cancers 2022, 14, 1207. https:// doi.org/10.3390/cancers14051207

Academic Editor: Emil Lou

Received: 3 February 2022

Accepted: 23 February 2022

Published: 25 February 2022

Publisher's Note: MDPI stays neutral with regard to jurisdictional claims in published maps and institutional affiliations.

Copyright: (C) 2022 by the authors. Licensee MDPI, Basel, Switzerland. This article is an open access article distributed under the terms and conditions of the Creative Commons Attribution (CC BY) license (https:// creativecommons.org/licenses/by/ $4.0 /)$.
Simple Summary: Tunneling nanotubes (TNTs) are a means of cell communication which have been recently discovered. They allow the intercellular trafficking of many types of cellular compounds ranging from ions, such as $\mathrm{Ca}^{2+}$, to whole organelles such as mitochondria. TNTs are found in many tissues, both in physiological and pathological conditions. They are also found in the brain where they contribute to brain development and function and also to degenerative diseases and glioma.

\begin{abstract}
Intercellular communication is essential for tissue homeostasis and function. Understanding how cells interact with each other is paramount, as crosstalk between cells is often dysregulated in diseases and can contribute to their progression. Cells communicate with each other through several modalities, including paracrine secretion and specialized structures ensuring physical contact between them. Among these intercellular specialized structures, tunneling nanotubes (TNTs) are now recognized as a means of cell-to-cell communication through the exchange of cellular cargo, controlled by a variety of biological triggers, as described here. Intercellular communication is fundamental to brain function. It allows the dialogue between the many cells, including neurons, astrocytes, oligodendrocytes, glial cells, microglia, necessary for the proper development and function of the brain. We highlight here the role of TNTs in connecting these cells, for the physiological functioning of the brain and in pathologies such as stroke, neurodegenerative diseases, and gliomas. Understanding these processes could pave the way for future therapies.
\end{abstract}

Keywords: tunneling nanotubes; mitochondria; brain; glioma; glioblastoma stem cells (GSCs); astrocytes; neurons; mesenchymal stem cells (MSCs); tumor microenvironment; degenerative brain diseases

\section{Introduction}

The first reports of intercellular connections through tunneling nanotubes (TNTs) date back to 2004 [1,2]. At the time, the description of these thin structures, observed mainly in vitro, provoked great skepticism from the scientific community. This skepticism did not fade, even though similar findings were generated by laboratories around the world. It took 13 years before the biological consequences of the occurrence of these tunneling nanotubes were finally fully acknowledged [3]. TNTs changed the paradigm of a cell which could no longer be defined as delimited by its own plasma membrane, as TNT-connected cells actually share their plasma membrane. In addition, components of their cytoplasms from the smallest (e.g., calcium ions) to the largest (e.g., mitochondrial organelles) were no longer to be considered their very own but mobile entities since they were recognized as exchangeable between TNT-connected cells. This led to the concept that cells can form dynamic transient networks allowing the exchange of information (through the exchange of specific cellular cargoes) which ultimately allows these cells to efficiently respond to cellular challenges such as tissue repair following injury or response to cancer therapy. 
From a holistic standpoint, TNTs are expected to be the basis for constantly evolving cellular networks, linking together many different cell types and allowing exchanges of very diverse cellular cargoes, and thereby giving rise to dizzying combinations of intercellular regulations. Reviews on the general features of these tunneling nanotubes, their structural and functional characterization, as well as the biological effects of the transported cargoes, are numerous and instructive [4-16], and we refer to them for further information.

The subject of this review concerns more specific points, which remain key questions in the field. The first is what is the current evidence that TNTs indeed occur in vivo and in tissues. This is obviously a critical consideration whose resolution has been hampered by technical challenges [17]. Fortunately, the development of organoids and the improvement of imaging techniques have allowed progress in this field, as detailed below. A second key point concerns the signals that stimulate TNT formation and intercellular cargo trafficking. As described below, these signals can consist of both intracellular signaling cascades and extracellular signaling triggers. Deciphering these signals is essential for understanding the mechanisms of TNT-dependent intercellular cargo exchange. It will also provide clues for designing tools, either to enhance cargo exchange when beneficial to the recipient cells as for tissue repair, or conversely to inhibit the process when it is detrimental as when supporting resistance to cancer therapy.

The brain is an organ where cellular communication is essential for the many tasks it governs. Many different means for this communication have been described. TNTs are now found to contribute to an additional layer of this intercellular communication as they have been reported to connect together various cells of the brain, including neurons, astrocytes, microglia and pericytes, all of which participate in brain physiology. Besides, TNTs appear instrumental for degenerative pathologies such as Alzheimer's disease (AD), CreutzfeldtJakob disease (CJD), Huntington's disease (HD) and Parkinson's disease (PD) (for reviews, refer to [18-20]. Brain cancer, in particular glioblastoma (GBM), is also a deadly disease. There too, TNTs promote disease progression, by allowing the microenvironment to support cancer cell proliferation and survival in response to treatment, as described below. It is expected and deeply wished that our growing knowledge of the biology inherent to these TNTs and to their transported cargoes will open up new avenues for cutting-edge research and for revolutionary therapeutic treatments for patients.

\section{Intercellular Communication through Tunneling Nanotubes (TNTs): A New Paradigm for Dynamic Cellular Interactions and Intercellular Exchange of Cellular Components}

The formation of tunneling nanotubes (TNTs) has now been observed in numerous cell types in vitro and in diverse biological conditions (i.e., physiology, tissue damage, and cancer). These TNTs are thin tubes (less than a micron in width) that connect cells together and allow the transport of various cargoes, ranging from small molecules such as ions, of which $\mathrm{Ca}^{2+}$ has been the most studied, to microRNAs, protein aggregates responsible for neuro-degenerative diseases, to whole organelles such as endoplasmic reticulum and mitochondria. These cargoes can be exchanged between cells due to the very specific nature of these TNTs that act as "open conduits" between the connected cells.

TNTs are the first intercellular nanotube structures described. Additional structures have since been described. Elegant cryoelectromicroscopy imaging showed that these individual TNTs can bundle up together, notably via N-cadherin binding, allowing the formation of tubular structures composed of multiple parallel TNTs [5,21]. Noteworthily, TNTs all appear to contain actin microfilaments which are determinant for TNT elongation and cargo trafficking [9].

Thicker cell-connecting tubes found in particular in tumors and called tumor-microtubes (TM) share many features of TNTs. In addition to actin microfilaments, they also contain microtubules which further support intercellular cargo transport and may contribute to the apparently longer lifespan of TMs compared to TNTs [22-29]. TMs and TNTs are not mutually exclusive as they were found to coexist in both glioblastoma organoids and 2D monolayer cultures $[27,30]$. This undoubtedly raises the question of what triggers one 
structure over the other and what are the biological consequences of the presence of either TNTs or TMs in tissues.

\section{TNTs and TNT-Mediated Intercellular Cargo Trafficking Occur in Tissues}

Even though TNTs have now been observed in many in vitro cell culture systems, the key question of their actual occurrence in tissues partly remains unclear. Demonstration of this presence was delayed by technical imaging challenges in the absence of specific TNT biomarkers. In addition to observing TNT- and TM-like cellular structures in resected tissues, such as tumors, observing tissues that are easily accessible due to their transparency, such as the retina, and tissue substitute systems such as organoids provide a more accurate picture of the extent of TNT/TM presence in tissue.

\subsection{TNTs in Resected Tissues}

Confocal microscopy was used to search for the presence of nanotube-like structures in surgical specimens. Such TNT structures were reported in whole-mount corneas of GFP chimeric mice between eGFP-expressing MHC class $\mathrm{II}^{+}$immune cells [31]. TNTs were also reported in human pleural mesothelioma and lung adenocarcinoma tumor specimens, with the caveat that these structures were visualized by the unexpected incorporation of Hoechst [32]. The use of fluorescent MitoTracker also enabled the visualization of TNTs in resected tissues from pancreatic ductal adenocarcinoma [33].

\subsection{Organoids as a Tissue Surrogate to Demonstrate the Existence of TNTs In Vivo}

Organoids are multicellular 3D-structures which aim at reproducing in vitro the anatomical structure of tissues with the goal of mimicking their in vivo functions. Tumor organoids are expected to allow to reproduce the tumor heterogeneity observed in vivo. Using such tumor organoids, the formation of both TNTs and TMs was observed among glioblastoma stem cells isolated from patients [27]. The formation of TNTs was also shown between human astrocytes and GBM cells in hyaluronic acid-gelatin based hydrogel $3 \mathrm{D}$ in vitro co-culture models [34]. Human cerebral organoid glioma (termed GLICO) were also developed from human embryonic stem cells and patient-derived glioma stem cells and shown to allow the formation of TMs which promoted the invasion capacity of the glioma cells [24].

Human cerebral organoids, also called mini-brains, can also be engineered through inkjet-bioprinting of cells, allowing the development of ex vivo structures that approximate the organization of the human brain in vivo, including the role of the neurovasculature [35]. These mini-brains have, as a goal, to recapitulate the physiological cell-cell and cell-matrix interactions which take place in a healthy brain and, beyond, to support the study of pathological disorders such as brain cancer and, besides, degenerative diseases such as Alzheimer's disease and Parkinson's disease and their responsiveness to therapy [35,36]. Such mini-brains were used to study the interactions between glioblastoma cells and other cells found in the brain, such as macrophages and endothelial cells [36,37]. Even though 3D-bioprinting techniques still need adjustments to get mini-brains closer to the cytoarchitecture of the brain, 3D imaging improvements [38] could make mini-brains a valuable experimental system, in the near future, to detect TNT formation in GBM, determine how they are regulated by therapy and, ultimately, how they can influence the glioma cell response to therapy.

\subsection{Murine In Vivo Models for the Observation of TNT Formation and Cargo Transfer}

\subsubsection{Murine Models of Intercellular Mitochondria Transfer}

The first evidence that mitochondrial transfer occurs in vitro was provided by landmark studies that documented mitochondrial transfer from MSCs to damaged bronchial epithelial cells in two murine models of acute lung injury triggered by rotenone and lipopolysaccharide (LPS), respectively $[39,40]$. Similarly, injection of $B 16 \rho^{\circ}$ mouse melanoma cells into syngeneic C57BL/6Nsu9-DsRed2 mice, which produce fluorescently labeled mi- 
tochondria, demonstrated in vivo transfer of mitochondria into these cells [41]. However, although these studies failed to properly provide information on the in vivo presence of TNTs, they have greatly advanced the field by documenting the in vivo occurrence of mitochondrial transfers.

\subsubsection{Murine Organs: Retina and Cornea}

A number of observations of the in vivo occurrence of TNTs were made in mice retina and cornea. This can be explained by the transparency of the ocular media which makes it accessible by optical in vivo imaging [42]. The retina is of particular interest since it constitutes by itself a structure of the central nervous system. TNTs could thus be observed between pericytes of the retina in NG2-DsRed murine models which express the red fluorescent protein (DsRed) under control of the NG2 promoter, thus allowing the selective visualization of retinal pericytes [43]. These actin-containing interpericyte TNTs (IP-TNTs), $0.5 \mu \mathrm{m}$ in diameter on average and up to $90 \mu \mathrm{m}$ in length, contained both mitochondria and calcium ions. Interestingly, intercellular $\mathrm{Ca}^{2+}$ waves could propagate between the IP-TNT-connected pericytes and were essential for neurovascular coupling [43].

The formation of nanotubes connecting photoreceptor neurons ( ${ }^{\mathrm{Ph}} \mathrm{NTs}$ ) was also observed in the mouse retina between transplanted and endogenous photoreceptors where they allowed the exchange of intracellular material, including proteins, mRNA and mitochondria in vivo [44]. Likewise, photoreceptors were shown to form NT-like structures in vitro, as either thin actin-containing NTs or thicker NTs (wider than 0.7 um) which also contained tubulin, allowing intercellular transfer of lysosomes and mitochondria [45]. Following transplantation of Nrl.Gfp ${ }^{+/+}$donor photoreceptors, these ${ }^{\mathrm{Ph}} \mathrm{NTs}$ were also observed in vivo between these GFP donor cells and the photoreceptors of the recipient eyes. Importantly, the use of chimeric mice showed that ${ }^{\mathrm{Ph}} \mathrm{NT}$-dependent process occurred both in the intact and damaged retina, suggesting a role of these ${ }^{\text {Ph }} \mathrm{NTs}$ in both transplanted retinas and in retinal physiology [45].

\subsubsection{Murine Cerebral Cortex}

TNTs were also detected between astrocytes and neurons in the cerebral cortex of mice expressing EGFP in astrocytes (AAV-GFAP-EGFP-p2A-cre murine models). By day 10 following viral injection, EGFP was found to transfer, through the F-actin-containing TNTs, from the EGFP-expressing astrocytes to the connected neurons [46].

\subsubsection{Xenografts of Human Tissues: Brain Tumors}

When tissue transparency is an issue, as for the brain, alternative experimental methods were adapted which consisted in implanting a cranial glass window following the opening of the mouse skull and transplanting of the patient-derived glioblastoma cells. Glioblastoma cells expressing the GFP fluorescent protein could be monitored and their connections through tumor microtubes detected by longitudinal intravital two-photon microscopy following their implantation into the mouse brain $[22,25,29,47]$. TNTs, or at least one consequence of their occurrence such as intercellular mitochondria transfer, were shown in xenografts of other cancer cell types such as acute myeloid leukemia (AML) [48].

\section{Molecular Determinants of TNT Formation and Cargo Intercellular Exchange}

A number of studies have been carried out with the goal of identifying the molecular mechanisms for TNT formation and cargo transport. This has led to the identification of a series of proteins, as detailed below and reported in Table 1. Moreover, triggers for these processes were also identified (see below and Table 2). Interestingly, some triggers of TNT formation were found to be effective in some cell types and not in others, suggesting cell type specificity in these processes (see also [9]). Establishing whether the currently identified mechanisms for TNT formation and cargo exchange will be general or specific to given cell types will likely require further work. 
Table 1. Proteins involved in TNT formation and cargo transport.

\begin{tabular}{|c|c|c|c|c|c|}
\hline & Proteins & Connected Cells & Molecular Mechanism & Cargo Transport & References \\
\hline \multirow{9}{*}{ 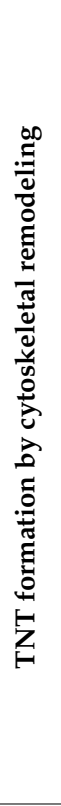 } & M-sec & $\begin{array}{l}\text { Raw264.7 } \\
\text { macrophages }\end{array}$ & $\begin{array}{c}\text { Interaction with Ral GTPase and exocyst } \\
\text { complex for cytoskeleton actin } \\
\text { remodeling }\end{array}$ & $\mathrm{Ca}^{2+}$ & Hase et al., 2009 \\
\hline & RalGPS2 & $\begin{array}{l}5637 \text { bladder cancer } \\
\text { cells, HEK } 293 \text { kidney } \\
\text { cancer cells }\end{array}$ & $\begin{array}{c}\text { Interaction with Akt and PDK1 leading } \\
\text { to activation of Akt/PI3K/mTOR } \\
\text { signaling } \\
\text { Interaction with RalA and LST1 }\end{array}$ & $\begin{array}{l}\text { Mitochondria RalA, } \\
\text { LST1 }\end{array}$ & D'Aloia et al., 2021 \\
\hline & Sec3/Sec5 & $\begin{array}{l}\text { Immune cells and } \\
\text { breast cancer cells }\end{array}$ & $\begin{array}{l}\text { Colocalization at the site of actin } \\
\text { cytoskeletal recruitment }\end{array}$ & Mitochondria & Saha et al., 2022 \\
\hline & ERp29 & $\begin{array}{l}\text { Osteosarcoma U2OS } \\
\text { cell line }\end{array}$ & Interaction with M-sec & $\begin{array}{l}\text { Mitochondria HIV } \\
\text { virus }\end{array}$ & Pergu et al., 2019 \\
\hline & LST-1 & $\begin{array}{l}\text { HeLa cells, } \\
\text { HEK-293T cells }\end{array}$ & $\begin{array}{c}\text { Assembly of M-sec and Ral GTPase at } \\
\text { the plasma membrane } \\
\text { leading to actin polymerization }\end{array}$ & DiI-labeled vesicles & Schiller et al., 2012 \\
\hline & Rac-1, Cdc42 & $\begin{array}{l}\text { RAW/LR5 } \\
\text { macrophages }\end{array}$ & $\begin{array}{l}\text { Activation of WASP \& WAVE2 followed } \\
\text { by Arp } 2 / 3 \text { complex } \\
\text { regulation of actin cytoskeleton }\end{array}$ & DiI labeled material & Hanna et al., 2017 \\
\hline & Myo10 & CAD cells & Not defined & DiD-labeled vesicles & Gousset et al., 2013 \\
\hline & \multirow{2}{*}{ Eps8 } & CAD cells & Bundling actin filaments & DiD-labeled vesicles & Delage et al., 2016 \\
\hline & & PC3 cells & Actin remodeling & CLU, YB-1 & Kretschmer et al., 2019 \\
\hline \multirow{3}{*}{ 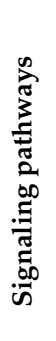 } & P53 & Astrocytes & $\begin{array}{c}\text { Upregulation of EGFR and } \\
\text { Akt/PI3K/mTOR, M-sec } \\
\text { overexpression } \\
\text { activation of Ral-exocyst complex }\end{array}$ & $\begin{array}{l}\text { ER, Golgi } \\
\text { endosomes } \\
\text { mitochondria }\end{array}$ & Wang et al., 2011 \\
\hline & Wnt/Ca ${ }^{2+}$ & CAD cells & $\begin{array}{l}\text { Activation of } \beta \text { CAMKII } \\
\text { actin polymerization/TNT stabilization }\end{array}$ & $\begin{array}{c}\text { DiD-labeled vesicles, } \\
\alpha \text {-synuclein }\end{array}$ & Vargas et al., 2019 \\
\hline & Rab35 & CAD cells & $\begin{array}{c}\text { Activation of ACAP2/inactivation of } \\
\text { ARF6 recruitment of EHD1 for TNT } \\
\text { formation }\end{array}$ & DiD-labeled vesicles & Bhat et al., 2020 \\
\hline \multirow{7}{*}{ 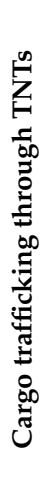 } & \multirow{2}{*}{ Miro-1 } & $\begin{array}{l}\text { MSCs and bronchial } \\
\text { epithelial cells }\end{array}$ & Not defined & Mitochondria & Ahmad et al., 2014 \\
\hline & & $\begin{array}{l}\text { Immune cells and } \\
\text { breast cancer cells }\end{array}$ & Not defined & Mitochondria & Saha et al., 2022 \\
\hline & \multirow{2}{*}{ Connexin 43} & $\begin{array}{l}\text { BMSCs and lung } \\
\text { epithelial cells }\end{array}$ & $\mathrm{Ca}^{2+}$ dependent mechanism & Mitochondria $\mathrm{Ca}^{2+}$ & Islam et al., 2012 \\
\hline & & Astrocytoma cells & Not defined & - & Osswald et al., 2015 \\
\hline & GAP43 & Neuronal cells & Not defined & $\mathrm{Ca}^{2+}$ & $\begin{array}{l}\text { Osswald et al., 2015; } \\
\text { Weil et al., } 2017\end{array}$ \\
\hline & Tthy1 & Neuronal cells & Not defined & - & Jung et al., 2017 \\
\hline & CD38 & $\begin{array}{l}\text { BMSCs and multiple } \\
\text { myeloma cell lines }\end{array}$ & Not defined & Mitochondria & Marlein et al., 2019 \\
\hline
\end{tabular}


Table 2. Regulation of TNT formation and cargo transport.

\begin{tabular}{|c|c|c|c|c|c|}
\hline & Stimuli & Connected Cells & Molecular Mechanisms & Cargo Transport & References \\
\hline \multirow{12}{*}{ 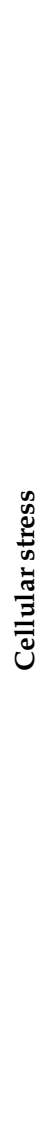 } & \multirow{7}{*}{$\begin{array}{c}\mathrm{ROS} \\
\left(\mathrm{H}_{2} \mathrm{O}_{2}\right)\end{array}$} & Neuronal CAD cells & Not defined & DiD-labeled vesicles & Gousset et al., 2013 \\
\hline & & $\begin{array}{c}\text { Astrocytes } \\
\text { T lymphocytes adult } \\
\text { mammalian stem cells } \\
\text { to } \\
\text { somatic cells }\end{array}$ & $\begin{array}{c}\text { mROS } \\
\text { cytochrome c } \\
\text { caspase } 3\end{array}$ & $\begin{array}{l}\text { Mitochondria, } \\
\text { Fas ligand }\end{array}$ & Rustom, 2016 \\
\hline & & $\begin{array}{l}\text { Astrocytes, } \\
\text { neurons }\end{array}$ & p53 activation & $\begin{array}{l}\text { ER, mitochondria, Golgi, } \\
\text { endosomes, } \\
\text { intracellular and } \\
\text { extracellular amyloid } \beta, \\
\text { Alexa488 dye }\end{array}$ & Wang et al., 2011 \\
\hline & & $\begin{array}{c}\text { Astrocytes } \\
\text { C6 glioma cells }\end{array}$ & p53 activation & Mitochondria & Zhang and Zhang, 2015 \\
\hline & & Astrocytes & p38 MAPK activation & $\begin{array}{c}\text { Colocalization of } \\
\text { myosin with F-actin in } \\
\text { the TNTs }\end{array}$ & Zhu et al., 2005 \\
\hline & & $\begin{array}{c}\text { AML cells, BMSC, } \\
\text { nonmalignant CD34+ }\end{array}$ & NOX2 & Mitochondria & Marlein et al., 2017 \\
\hline & & HEK 293 cells & RalGPS2-RalA pathway & - & D'Aloia et al., 2021 \\
\hline & \multirow{2}{*}{$\begin{array}{l}\text { Acidic } \\
\text { microenvironment }\end{array}$} & Mesothelioma cells & mTOR pathway & $\begin{array}{l}\text { Vesicles, proteins, } \\
\text { mitochondria }\end{array}$ & Lou et al., 2012 \\
\hline & & $\begin{array}{l}5637 \text { bladder cancer } \\
\text { cells }\end{array}$ & RalGPS2 upregulation & $\begin{array}{c}\text { Mitochondria, RalA, } \\
\text { LST1 }\end{array}$ & D'Aloia et al., 2021 \\
\hline & Sorum donrivation & $\begin{array}{l}\text { Neurons } \\
\text { astrocytes }\end{array}$ & Akt, PI3K and mTOR & Amyloid beta & Wang et al., 2011 \\
\hline & serum ueprivation & $\begin{array}{l}5637 \text { bladder cancer } \\
\text { cells }\end{array}$ & RalGPS2 upregulation & $\begin{array}{l}\text { Mitochondria, RalA, } \\
\text { LST1 }\end{array}$ & D'Aloia et al., 2021 \\
\hline & Tissue damage & $\begin{array}{l}\text { S24 and T269 } \\
\text { glioma cell lines }\end{array}$ & - & - & Weil et al., 2017 \\
\hline \multirow{4}{*}{ 苞 } & $\begin{array}{l}\alpha \text {-particle } \\
\text { radiation }\end{array}$ & $\begin{array}{l}\text { Glioblastoma } \\
\text { U87 cells }\end{array}$ & - & - & Matejka et al., 2020 \\
\hline & Doxorubicin & $\begin{array}{c}\text { Pancreatic } \\
\text { adenocarcinoma }\end{array}$ & - & Chemotherapeutic drug & Desir et al., 2018 \\
\hline & Cytarabine & AML, BMSCs & - & Mitochondria & Moschoi et al., 2016 \\
\hline & Temozolomide & Glioblastoma cells & - & $\begin{array}{c}\text { Receptors (CCR5, CXCR4, } \\
\text { LRP1) } \\
\text { mitochondria } \\
\text { Vesicles, MGMT }\end{array}$ & Valdebenito et al., 2020 \\
\hline \multirow{3}{*}{ 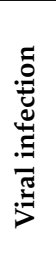 } & Nef (HIV-1) & MDM & M-Sec Signaling cascade & HIV & Hashimoto et al., 2016 \\
\hline & $\begin{array}{c}\text { HMPV P } \\
\text { phosphoprotein }\end{array}$ & $\begin{array}{l}\text { Lung epithelial } \\
\text { BEAS-2B cells }\end{array}$ & $\begin{array}{c}\text { Stimulation of GTPases } \\
\text { involved in actin } \\
\text { polymerization }\end{array}$ & $\begin{array}{l}\text { HMPV N protein HMPV } \\
\text { particles }\end{array}$ & El Najjar et al., 2016 \\
\hline & $\begin{array}{l}\text { US3 protein kinase } \\
\text { (Pseudorabies) }\end{array}$ & $\begin{array}{l}\text { Swine testicle (ST) cells; } \\
\text { RK13 cells }\end{array}$ & $\begin{array}{l}\text { E-cadherin } \\
\beta \text {-catenin }\end{array}$ & $\begin{array}{l}\text { GFP, mitochondria, } \\
\text { virions-containing } \\
\text { vesicles }\end{array}$ & Jansens et al., 2017 \\
\hline \multirow{4}{*}{ 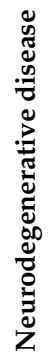 } & $\begin{array}{c}\text { Infectious prions } \\
\text { PrPSc }^{S}\end{array}$ & Neuronal CAD & $\begin{array}{c}\text { Colocalization of PrPSc } \\
\text { with EEA1 } \\
\text { and Vamp3 }\end{array}$ & $\begin{array}{l}\text { Endosomes containing } \\
\text { PrPSc cells }\end{array}$ & Zhu et al., 2015 \\
\hline & $\alpha$-synuclein (PD) & Neurons & - & $\begin{array}{c}\text { Lysosomal vesicles } \\
\text { containing } \\
\alpha \text {-synuclein }\end{array}$ & $\begin{array}{l}\text { Abounit et al., } \\
\text { 2016a, 2016b }\end{array}$ \\
\hline & mHTT (HD) & CAD neuronal cells & - & mHTT aggregates & Costanzo et al., 2013 \\
\hline & Tau (AD) & $\begin{array}{l}\text { Neurons } \\
\text { CAD cells }\end{array}$ & $\begin{array}{l}\text { Tau co-localization with } \\
\text { actin in TNTs }\end{array}$ & Tau aggregates & Tardivel et al., 2016 \\
\hline
\end{tabular}




\subsection{Cell Components and Signaling Pathways Involved in TNT Formation and Cargo Trafficking}

\subsubsection{Proteins Linked to TNT Formation by Cytoskeletal Remodeling}

The TNTs all appear to contain actin microfilaments, while the thicker ones also have a microtubule cytoskeleton [16], therefore warranting studies on the role of proteins involved in cytoskeletal remodeling in the process of TNT formation [49,50]. From this perspective, the cytosolic protein M-Sec, also known as B94, was shown to interact with Ral GTPase and the exocyst complex involved in the cytoskeleton actin remodeling. Knocking down either M-Sec or Ral GTPase suppressed TNT formation and reduced the propagation of calcium flux between Raw264.7 murine macrophages [50]. The M-Sec-dependent TNT formation was shown to require its interaction with the endoplasmic reticulum chaperone protein ERp29, as demonstrated in the human osteosarcoma U2OS cell line [51]. Moreover, the transmembrane MHC class III protein leukocyte specific transcript 1 (LST-1) was also identified for its role in assembling different proteins, including M-Sec and RalA, involved in tunneling nanotube formation [52]. RalGPS2 is a Ras-independent guanine nucleotide exchange factor for the RalA GTPase. It was demonstrated to allow TNT formation in bladder and kidney cancer cells through its interaction with Akt and PDK1, leading to activation of the Akt/PI3K/mTOR pathway, as well as with LST-1 and RalA [53]. The exocyst complex has been further involved in TNT-mediated cargo trafficking as Sec3 and Sec5 proteins, which are part of this complex, were identified at the site of actin cytoskeleton recruitment in TNTs between natural killer cells and MDA-MB-231 breast cancer cells and shown to promote mitochondria trafficking between these cells [54]. In addition to the RalA GTPase, the two Rho GTPases Rac1 and Cdc- 42 have been involved in TNT formation, in RAW/LR5 macrophages, by allowing the activation of their downstream effectors WAVE2 and WASP, respectively [49]. Eps8 (Epidermal growth factor receptor pathway 8) is another factor interacting with PI3K. Eps8 regulates actin remodeling. The role of Eps8 for TNT formation was shown in PC3 and LNCaP prostate cancer cells [55]. More precisely, its actin filament bundling activity was shown essential for TNT induction in neuronal CAD cells [56]. Finally, the actin-based molecular motor myosin-X (Myo10) was also demonstrated to favor TNT formation between neuronal CAD cells [57].

\subsubsection{Signaling Pathways Involved in TNT Formation}

Under oxidative stress, triggered by hydrogen peroxide $\left(\mathrm{H}_{2} \mathrm{O}_{2}\right)$ or serum depletion, p53 activation and the consequent upregulation of EGFR expression and Akt/PI3K (phosphoinositide 3-kinase)/mTOR (mammalian target of rapamycin) activation were found to promote the establishment of TNTs among astrocytes, possibly through M-Sec and the exocyst complex [58]. In murine CAD neuronal cells, the $\mathrm{Wnt} / \mathrm{Ca}^{2+}$ pathway was shown to contribute to both TNT formation and cargo trafficking through TNTs [59]. Activation of $\mathrm{Ca}^{2+} /$ calmodulin-dependent protein kinase II (ßCAMKII) by the Wnt/ $\mathrm{Ca}^{2+}$ pathway was proposed to support TNT formation through a two-step mechanism, involving Wnt $/ \mathrm{Ca}^{2+}$-dependent detachment and subsequent reattachment of $\beta C A M K I I$ to the actin cytoskeleton [59]. Noteworthily, the Rab GTPase protein Rab35 and its downstream signaling through ACAP2 (Arf-GAP with coiled-coil, ankyrin repeat and PH domain 2), ARF6-GDP and EHD1 (EH domain-containing 1) also promoted TNT formation in CAD cells [60].

\subsubsection{Proteins Involved in Cargo Trafficking through TNTs}

Miro-1 (mitochondrial Rho GTPase-1) was found essential for the mitochondrial trafficking between mesenchymal stem cells (MSCs) and lung bronchial epithelial cells in a murine model of lung injury (Ahmad et al., 2014). Miro-1 expression in MDA-MB231 breast cancer cells is important for the TNT-mediated acquisition of mitochondria from natural killer cells [54]. The role of the gap junction protein connexin 43 (Cx43) was shown in vivo for the connection of BMSCs to lung epithelial cells, in a murine model of lung damage, and for TM connections between astrocytoma cells, allowing mitochondria and calcium intercellular exchange, respectively $[25,40]$ (see also [61,62] for review). Two 
neuronal proteins, the growth associated protein (GAP-43) and Tweety-homolog 1 (Tthy1), were also described as molecular drivers of TM formation and function, as shown in glioma in vivo models $[22,25,47]$. Finally, in multiple myeloma, the membrane protein CD38 was also reported to support TNT formation and mitochondrial transfer from bone marrow stromal cells, as shown in vitro and in vivo after implantation of CD38 KD cells in NSG mice [63].

\subsection{Extracellular Triggers and Regulators of TNT Formation and Cellular Cargo Exchange}

A key question about TNTs is what are the physiological and pathological conditions which regulate these intercellular communications and the cargo trafficking that ensues. It is now generally acknowledged that cellular and metabolic stress trigger TNT formation. Among the known ROS (reactive oxygen species), hydrogen peroxide $\left(\mathrm{H}_{2} \mathrm{O}_{2}\right)$ constitutes an important trigger of TNT formation as shown for instance for rat astrocytes, murine neuronal CAD cells and cocultures of rat astrocytes and $\mathrm{C} 6$ glioma cells $[57,58,64-66] . \mathrm{H}_{2} \mathrm{O}_{2}$ also enhanced the formation of TNTs and mitochondrial transfer from human bone marrow stromal cells (BMSCs) to CD34 ${ }^{+}$cells from patients with acute myeloid leukemia (AML), an effect relying on the NADPH oxidase-2 (NOX2)-dependent production of ROS [67].

Other extracellular stimuli can support cellular metabolic stress. They include acidic microenvironment ( $\mathrm{pH} 6.6)$, hypoxia $\left(1 \% \mathrm{O}_{2}\right)$, and serum starvation $[32,53,55]$. These metabolic stress induced TNT formation in human PC3 and LNCaP prostate cancer cell lines via the stress-induced chaperones clusterin (CLU) and YB-1 (Y-box binding protein1) and PI3K/Akt activation [55]. Similarly, serum depletion induced TNT formation in human malignant pleural mesothelioma [32]. Interestingly, these stimulatory triggers were shown to act in a cell type-specific manner, promoting TNT formation in some cell types but not in others. As an example, oxidative stress $\left(\mathrm{H}_{2} \mathrm{O}_{2}\right)$ promoted TNT formation in HEK293 cells while it had no effect on 5637 bladder cancer cells. On the other hand, 5637 cells showed greater TNT formation under acidic conditions as well as under serum deprivation conditions [53]. Besides, as expected from the observed TNT stimulatory effect of PI3K/Akt/mTOR signaling, inhibition of mTOR activity, by rapamycin or by the rapamycin derivative everolimus, suppressed TNT formation in murine astrocytes and human mesothelioma MSTO-211H cells, respectively [32,58].

Tissue damage, localized at a drug injection site or to the larger area of tumor resection, was also identified as sufficient cellular stress to trigger TNT formation [31,47]. Moreover, cancer therapy itself can constitute a tissue insult sufficient to stimulate TNT formation, as shown following $\alpha$-particle radiation of U87 glioblastoma cell line or doxorubicin, cytarabine and temozolomide chemotherapeutic treatments in human pancreatic cell lines, human AML blasts and human glioblastoma cell lines respectively [33,48,68,69].

Pathologies can also generate cellular modifications which support TNT formation. During viral infection with the human immunodeficiency virus HIV-1, the viral protein Nef, together with the cellular protein M-sec, were shown to stimulate TNT formation in monocytes derived macrophages (MDMs) [70]. Likewise, metapneumovirus (HMPV) infection of human bronchial epithelial BEAS-2B cells generated an increased number and longer TNTs mediated by the HMPV P phosphoprotein [71]. The alphaherpesvirus US3 protein kinase also induced the formation of stable TNTs, allowing the transport of pseudorabies virions and allowing alphaherpesvirus spread [72].

In the development of neurodegenerative diseases, infectious prion $\mathrm{PrP}^{\mathrm{Sc}}, \alpha$-synuclein, mutant Huntingtin (mHTT) and Tau aggregates have been shown to increase TNT formation and consequently facilitate the intercellular transfer of the toxic protein aggregates, leading to the spreading of the disease to other cells [73-77]. It should be noted that, in addition to the misfolded protein aggregates they generate that promote TNT formation, cells with neurodegenerative diseases also produce $\mathrm{H}_{2} \mathrm{O}_{2}$ which, as discussed above, can further contribute to TNT formation [78,79]. 


\section{Focus on an Organ: The Brain Role of Intercellular Communication in Physiology and Pathology}

The brain contains many different cell types including neurons, astrocytes, oligodendrocytes, microglia, and endothelial cells. Intercellular communication between these different cell populations is essential for maintaining the homeostasis of the central nervous system (CNS) [80-82]. Communication between these cells is mediated by various means, which can rely on diffusible paracrine factors, such as neurotrophic factors and neuropeptides or on extracellular vesicles (EVs). Communication between brain cells may also rely on voltage-gated channels, active membrane transporters, and diffusion channels, as thoroughly reviewed elsewhere [83]. Furthermore, intercellular communication can rely on the close proximity of interacting cells, as for chemical and electrical synapses, or require physical contacts as it is the case for gap junctions and TNTs, as detailed below.

\subsection{Cell Communication through Paracrine Secretion in the Healthy Brain}

\subsubsection{Communication through Soluble Factors}

A flurry of studies have provided evidence that soluble factors secreted by neural, glial and microglial cells as well as by cells of the blood-brain barrier, such as endothelial cells end pericytes, play a prominent role in the regulation of neurogenesis and gliogenesis processes [84]. Astrocytes, the most abundant cells in the CNS, are also considered the most potent secretory glial cells capable, through their secretome, of controlling the behavior and activities of neurons, oligodendrocytes, microglia, endothelial cells and pericytes. This secretome includes ciliary neurotrophic factor (CNTF), bone morphogenetic protein (BMP), brain-derived neurotrophic factor (BDNF), fibroblast growth factor 2 (FGF2), nerve growth factor (NGF), platelet derived growth factor-AA (PDGF-AA), vascular endothelial growth factor (VEGF), transforming growth factor- $\beta$ (TGF- $\beta$ ), glial cell line-derived neurotrophic factor (GDNF), tumor necrosis factor- $\alpha$ (TNF $\alpha)$, IL-6, IL-1 $\beta$, IL-10, and IL-33 [85-89].

In addition to astrocytes, many other cells of the brain communicate through their paracrine activity $[87,90]$, as evidenced by:

(i) the crosstalk between neurons and CNS stem cells via the secretion by neurons of BDNF, neurotrophin-3 and BMP, which leads to the neuronal differentiation of CNS stem cells [84]. Neurons also promote the proliferation/differentiation of oligodendrocytes and Schwann cells via their secretion of neuroregulins, such as glial growth factor 2 (GGF2) [91],

(ii) the BDNF-dependent modulation by oligodendrocytes of synapse activity in neurons [92]

(iii) the regulation of astrocyte differentiation by endothelial cells, through leukemia inhibitory factor (LIF) release [93], and finally,

(iv) the role of microglia in promoting neuroprotection and neurogenesis through the production of BDNF [94], IGF-1 [95], TGF- $\beta$ [96] and arginase 1 [97].

Other factors, in addition to growth factors and cytokines, allow brain cells to communicate with each other. For instance, neurons and astrocytes communicate with surrounding cells through the secretion of (i) neurotransmitters such as glutamate, ATP, and GABA; (ii) neurotransmitter precursors such as glutamine and proenkephalin (PENK); (iii) neuromodulators such as D-serine; (iv) peptides and hormones such as atrial natriuretic peptide and thyroid hormones; (v) eicosanoids and metabolic substrates such as lactate, citrate and glucose; and (vi) ROS scavengers including glutathione and ascorbate (for review, see [98]).

\subsubsection{Communication through Extracellular Vesicles}

Brain cells can interact with each other through the secretion and internalization of extracellular vesicles (EVs) including exosomes and microvesicles. In the brain, EVs were shown to carry diverse cargoes including growth factors and cytokines, signaling proteins, lipids as well as genetic material including mRNA, miRNA, long non-coding RNA (lncRNA), and mtDNA [99]. This diversity can explain why EV-mediated crosstalk exerts a wide range of biological effects. For instance, microglia-derived EVs containing inflammatory cytokines and GAPDH trigger the propagation of inflammatory signaling throughout 
the brain [100] while EVs carrying endocannabinoid N-arachidonoylethanolamine (AEA) on their surface inhibit the synaptic transmission between neurons by abrogating GABA release [101] and enhancing their sphingolipid metabolism [102]. As another example, EVs produced by astrocytes containing Apolipoprotein D or miR-92b-3p have been found to exert neuroprotective and neuroregenerative effects after exposure to ATP, IL-10 or ischemic insult $[103,104]$. Finally, the release of miR-124-3p-containing exosomes from neurons has been reported to decrease inflammation in the brain, by suppressing activation of neuro-inflammatory M1 microglia and A1 astrocytes [105].

\subsection{Cell Communication through Gap Junctions}

Cell communication can also occur through direct physical interactions, as it is the case for gap junctions. Gap junctions (GJs) are intercellular channels composed of connexins. These structures allow the diffusion of small molecules including ions, neurotransmitters, second messengers and metabolites between connected cells. GJ-mediated communications are involved in the transmission and propagation of neuronal signals, potassium clearance at the synaptic level and calcium signaling [106]. For instance, astrocytes that abundantly express connexin 43 (Cx43) communicate through (i) Cx43/Cx43 GJs with other astrocytes for the synchronization of their activities [107]; (ii) through Cx43/Cx47 GJs with oligodendrocytes to promote myelination [108]; and (iii) through Cx43/Cx36 GJs with neurons to improve their survival [107]. In addition, Cx43 is abundantly expressed at astrocytic endfeet that contact blood vessels, where it plays a critical role in maintaining the integrity of the brain blood barrier [109]. Gap junctions are also important components of electrical synapses as they allow the passive flow of electrical currents between pre-and post-synaptic neurons, resulting in the generation of post-synaptic action potential [110].

\subsection{Cell Communication through TNTs}

Several in vitro and in vivo studies have reported that brain cells communicate through intercellular-TNT mediated connections. Based on the ability of TNTs to mediate the transfer of a broad range of cellular compounds including ions, proteins, vesicles, genetic material and of organelles such as lysosomes or mitochondria, these structures have been suggested to be implied in neonatal brain development and adult brain homeostasis [16]. In particular, several in vitro and in vivo studies have reported the TNT-mediated connection between astrocytes and neurons in neonatal and adult brain [111-113].

In the neonatal brain, TNT-mediated crosstalk has been shown to mediate electrical coupling and calcium wave propagations between astrocytes and immature neurons [113]. Since calcium signaling was reported to be involved in the proliferation, migration and differentiation of immature neurons [114], these observations suggest that astrocytes contribute to neuronal maturation through TNTs. This hypothesis was further strengthened by studies revealing the presence of TNT structures linking astrocytes and neurons, as observed in mouse neonatal brain slices [111,112]. In addition, TNT connections have been observed amongst pericytes and between pericytes and endothelial cells in human fetal brain, suggesting that these structures may play a role in the early phases of brain vascularization [115].

In the adult brain, the crosstalk of astrocytes and neurons by the means of TNTs has been reported in vivo, although the exact contribution of this phenomenon to the maintenance of homeostasis in the healthy adult brain remains unclear [46]. Still, in vivo studies suggest that TNTs are involved in the regulation of brain function. For instance, TNTs have been involved in the regulation of neurovascular coupling and in the adaptation of blood flow to neuronal activity by allowing the transfer of calcium ions between interconnected pericytes [43].

Another function of TNTs is their ability to detoxify the healthy brain from toxic cellular compounds such as misfolded proteins that can accumulate in neurons but also in astrocytes and microglia [116]. In particular, TNTs have been found in vitro to convey fibrillar $\alpha$-synuclein ( $\alpha$-syn) cargoes from $\alpha$-syn -overloaded astrocytes to microglia where 
it is degraded. Similarly, it was recently reported that $\alpha$-syn-overloaded microglia have the capacity to form TNTs, as observed both in vitro and in vivo, allowing them to discharge their excessive $\alpha$-syn aggregate contents to neighboring naive microglia, which take care of their clearance [117]. Beyond their role in $\alpha$-syn degradation, the TNTs that connect naive microglia to affected microglia have also been shown to mediate the transfer of mitochondria to these affected microglia, thereby preventing cell death and inflammation [117]. Finally, TNT-mediated transfer of misfolded protein aggregates between neurons has been documented in vitro in several studies $[59,74,75]$. Interestingly, protein assemblies were transferred along TNTs inside lysosomes, presumably for their degradation by neurons initially devoid of these toxic compounds [74].

\subsection{Stroke-Role of TNTs in Regeneration}

The formation of TNTs can be increased in the brain under stress conditions, including ischemic and oxidative insults [64]. Acute ischemic damage causes dramatic mitochondrial dysfunction in neurons, jeopardizing their viability, and TNT-mediated mitochondrial transfer appears to be an adaptive mechanism for maintaining mitochondrial function in the damaged brain and promoting recovery after stroke [118]. Excess ROS production by damaged cells has been shown to trigger TNT formation, notably in hydrogen peroxide-injured astrocytes [66,119], leading to mitochondria transfer from the healthy to the damaged cells $[12,64,120]$.

Most brain cells, including astrocytes, neurons, microglia, and endothelial cells, have been reported to respond to stroke or stroke-mimicking damage conditions by TNT formation and mitochondria transfer, in a pro-survival mechanism. This was shown in vitro for the transfer of mitochondria from healthy neurons and astrocytes to stressed neurons, supporting their rescue [121-123]. By a similar mechanism relying on TNT-mediated mitochondria transfer, neural stem cells could protect apoptotic brain microvascular endothelial cells against cell death, as shown in vitro and in vivo [124].

In addition to transporting healthy mitochondria to damaged cells, TNTs also participate in neuro-regenerative processes by conveying cargoes, such as dysfunctional cellular compounds or stress signals, thereby eliciting an adaptive repair response in recipient cells. As an example, neurons were shown to release dysfunctional mitochondria to astrocytes, leading to their degradation and disposal [125]. It is worth noting that, outside of the brain, the transfer of dysfunctional mitochondria from damaged cells to healthy cells, such as MSCs, has also been shown to be sensed as a stress signal leading to the activation of tissuerepair processes [120,126]. Accordingly, a similar TNT-mediated phenomenon could occur in the ischemic brain where damaged nerve cells could transfer dysfunctional mitochondria to healthy cells (including nervous stem cells), thereby triggering a regenerative response to brain injury.

Brain ischemia was also reported to increase TNT communication between microglia and neurons, a process that may confer neuroprotection by ensuring microglia removal of neuronal debris and regulating inflammation $[127,128]$. Finally, mast cells were also shown to communicate with each other in vitro, through TNT-mediated transfer of secretory granules and mitochondria [129]. Mast cells are long-lived cells and major effectors of allergic inflammation which are also found in the brain $[130,131]$. It was hypothesized that mast cells could thus rapidly spread stress signals to neighboring cells to alert them of harmful conditions [129].

Beside their positive effects in stroke recovery, TNT communications may also be detrimental to recipient cells, as suggested by Bittins and Wang [132]. They showed that UV-treated apoptotic neurons transferred through TNTs pro-phagocytic signals, including phosphatidylserine, oxidized phospholipids and calreticulin, to cocultured viable neurons, leading to their phagocytosis by macrophages [132]. Finally, damaged brain cells, including neurons and astrocytes, were reported to communicate with each other through TNTs. Whether this phenomenon is beneficial or detrimental in the context of ischemic brain repair is not yet known $[66,133,134]$. 


\subsection{Degenerative Brain Diseases}

TNTs allow the spreading and progression of neuronal diseases such as Alzheimer's disease (AD), Creutzfeldt-Jakob disease (CJD), Huntington's disease (HD) or Parkinson's disease (PD) through the intercellular dissemination of their respective pathogenic agents: Tau and amyloid- $\beta$ aggregates for $\mathrm{AD}[73,76,135], \mathrm{PrP}^{\mathrm{Sc}}$ prions for CJD [136], mutant huntingtin aggregates for HD [75,137], and $\alpha$-synuclein ( $\alpha$-syn) aggregates for PD $[74,116,138,139]$. Interestingly, in addition to the dissemination of toxic protein aggregates, the intercellular exchange of mitochondria via TNTs were also proposed to promote the progression of Parkinson's disease [140].

\section{Brain Tumors}

Among brain tumors, glioblastoma (GBM) stands out as the most devastating, with an associated bleak prognosis. This is often related to a delayed diagnosis of the tumor, to the point where it already spread to an important area of the brain and therefore impairs cognitive functions. Full GBM surgical resection can be made difficult by the infiltrative nature of these tumors and by the need to preserve essential cognitive functions of the patients. From a cellular standpoint, the difficulty in efficiently treating glioblastoma also stems from the high heterogeneity and plasticity of these tumors, beyond the still debated question of the cell of origin of these tumors [141-146].

The glioblastoma stem cells (GSCs) present in GBM widely contribute to GBM recurrence following surgery and to resistance to both radio- and chemotherapies $[144,147,148]$. These GSCs undergo highly dynamic changes of their genetic, epigenetic, and metabolic features, which supports their escape from GBM therapies [149]. Asymmetric cell division of GSCs also contributes to the generation of GSCs endowed with increased prosurvival features [150]. Moreover, these dynamic changes are supported by evolving interactions between GSCs and their microenvironment, via cytokines/chemokines, extracellular vesicles, and TNT/TM-mediated cargo exchange $[23,149,151-153]$.

\subsection{Biological Effects of Cell-Cell Connections among Glioblastoma Cells}

As mentioned above, the Winkler laboratory has helped advance in the field by developing orthotopic xenograft models. Implantation of labeled glioblastoma stem-like cells into mice skulls, followed by longitudinal intravital two-photon laser scanning microscopy, allowed for the observation of tumor microtube formation in vivo as well as of their effects on glioblastoma progression $[22,25,29,47]$. TM connections between glioblastoma cells were found to induce stemness features in these cells, as shown by RNA-seq analysis and increased expression of the stemness marker Nestin. This was linked to an increased capacity of glioblastoma cells to reinitiate tumor growth [29]. TM-connected glioblastoma cells also demonstrated enhanced proliferation and invasion capacities [25]. Importantly irradiation of the tumors, 60 days after tumor implantation in the mice brains, showed higher survival of the TNT-connected glioma cells, demonstrating higher resistance to radiotherapy $[22,25,29]$. Likewise, temozolomide treatment of the glioma xenografts, at D85 following engraftment, demonstrated higher survival in the highly connected glioblastoma cells, indicating enhanced chemoresistance of these cells [47].

Human glioma organoids obtained from patient-derived glioma stem cells also constitute valuable experimental approaches for deciphering the role of TNTs in glioma progression. They were shown to allow the formation of both tunneling nanotubes and tumor microtubes [24,27]. Glioma cells connected by TMs demonstrated an enhanced capacity to invade the surrounding normal host tissues [24]. The use of glioblastoma stem cells expressing fluorescent mitochondria (MitoGFP) also showed mitochondria trafficking through the TNT-like structures. The percentage of mitochondria-receiving cells increased over the 23 days of glioblastoma organoid culture, demonstrating dynamic cellular interactions and mitochondrial exchange among GSCs [27].

TNTs among GBM cells were also shown to allow the transfer of the DNA repair enzyme $\mathrm{O}^{6}$-methylguanine-DNA methyltransferase (MGMT), from MGMT-expressing 
GBM cells to MGMT-defective GBM cells [69]. As the expression of MGMT by glioblastoma cells has been linked to resistance to the alkylating agent temozolomide, this TNT-mediated transfer of MGMT was proposed as spreading this MGMT-based resistance to TMZ among GBM cells.

\subsection{Effect on Glioma Progression of TNT Connections between Glioma Cells and Other Cells of the Brain}

The nervous system plays a major role in glioma initiation and progression, notably due to the interactions that neurons, astrocytes and glial cells can develop with glioma cells [154]. TNT-mediated connections were reported between rat astrocytes and glioma cells, where they were found to increase glioma cell proliferation [65]. Interestingly, human astrocytes were also observed to form TNTs with glioma cells, in 2D and 3D-cocultures which, in this case, resulted in increased GBM cell proliferation and resistance to chemicals including temozolomide, clomipramine and vincristine [34]. Conversely, TNT connections between human GBM cells and non-tumor astrocytes, and the resulting transfer of mitochondria from GBM cells to astrocytes, were shown to allow the tumor cells to modify the tumor microenvironment [155]. Interestingly, the TNTs formed between U87-MG cells (as a model of GBM cells) were found to be thicker than those formed between NHA astrocytes, raising the possibility of using these structures for therapeutic purposes, for instance with liposomes as drug delivery vehicle [156].

As a matter of fact, intercellular mitochondria transfers have been shown in many instances to support proliferation and resistance of cancer cells as well as repair of damaged cells (for review see $[12,14]$ ). In the brain, mitochondria transfer from astrocytes was shown to contribute to the rescue of cisplatin-treated neurons [157]. TNT-mediated mitochondria transfers have been observed between human mesenchymal stem cells (MSCs) and glioblastoma stem cells in vitro [8,14]. The transfer of MSC mitochondria to GSCs, by the experimental procedure of 'Mitoception' [158-160], allowed researches to demonstrate that MSC mitochondria enhance the energy metabolism of the GSCs in a dose-dependent manner, as well as their resistance to temozolomide treatment (Nakhle et al., unpublished results), thus further supporting the role of the glioblastoma microenvironment and of mitochondrial transfers in GBM progression.

\section{Conclusion What's Next in the Field?}

In this field of intercellular connections through TNTs/TMs, which is now evolving at an accelerated pace, many experimental data were obtained recently, mainly due to novel techniques and experimental approaches, as mentioned in this review. Nonetheless, a number of questions still remain unanswered. Among these, the exact biophysical characteristics of these intercellular structures and the mechanisms involved in cargo transport still need to be determined. TNTs exist in different flavors, such as individual TNTs, bundles of individual TNTs, and thicker TNTs (also known as tumor microtubes). It is not known what triggers the formation of one of these structures rather than the others. Beyond the mere biophysical properties of these structures, expected to be distinct for each of them, addressing this question could become a priority if each type of these intercellular connections were to be more prone to convey specific cellular cargoes. This leads to the related question of how donor cells decide which organelles, molecules or signals they transfer through TNTs to the recipient cells and, conversely, whether recipient cells can request specific cargoes from their neighboring cells, to meet their needs.

TNTs have been shown to connect cells of either similar cell types, sometimes with different biological status, or alternatively cells of different cell types. This raises the question of the cell features which determine the direction of cargo trafficking between the TNT-connected cells. Is it just a matter of intracellular concentrations of the transported cargoes? Or is it rather the biological context, for instance physiological versus pathological? In the latter case, is there an influence of local inflammatory conditions with their payload of circulating cytokines? Alternatively, is it the metabolic state of the tissues, including the production of reactive oxygen species (ROS) as mentioned above, that determines the 
exact nature of the TNT-transported cargo? This would mean that the cellular and tissue microenvironment would play a major role on the exchanged cargoes and the resulting cellular functions.

Finally, if we consider the cellular complexity of a tissue or organ, what percentage of these cells are connected through TNTs at any given time? Is the dizzying vision of a matrix of connections linking all cells and allowing real-time exchange of a diversity of cellular constituents a reality? As described above, tissue imaging allowed thorough progress and the establishment of the actual occurrence of these TNTs as well as the identification of some cellular cargoes in vivo. However, following the real-time trafficking of all possible cargoes in vivo, as well as their combined functional effects, is another challenge that will require further work. Future findings in this field will be valuable to determine the exact in vivo contribution of TNTs, both in maintaining tissue homeostasis in physiological conditions and in promoting tissue repair following injury. In addition, it will be of primary importance to assess to what extent TNTs are responsible for the initiation or aggravation of brain diseases, including cancer or neurodegenerative diseases such as Parkinson's or Alzheimer's syndromes. Therefore, for now, we can speculate that we are only seeing the tip of the iceberg regarding the extent and biological effects of these TNT-mediated cargo exchanges in tissues.

Author Contributions: Writing, K.E.K., J.S., A.-M.R. and M.-L.V. All authors have read and agreed to the published version of the manuscript.

Funding: Support from the Agence Nationale pour la Recherche (ANR-MiMeTic), Fondation ARC pour la Recherche sur le Cancer, INCa-Cancéropôle GSO, Fondation de l'Avenir (AP-RM-19-001), Ligue Contre le Cancer, Région Occitanie-GliMit and SATT-AxLR is gratefully acknowledged.

Acknowledgments: K.E.K. and J.S. had financial support from Région Occitanie and Ligue Contre le Cancer respectively. A.-M.R. and M.-L.V. are staff scientists from the National Institute for Health and Medical Research (INSERM) and the National Center for scientific research (CNRS), respectively. We thank Jean-Philippe Hugnot and Jean Nakhle for reviewing of the final manuscript.

Conflicts of Interest: The authors declare no conflict of interest associated with the manuscript.

\section{Abbreviations}

$\begin{array}{ll}\text { ACAP2 } & \text { Arf GAP with coiled coil: ankyrin repeat and PH Domains } 2 \\ \text { AD } & \text { Alzheimer's disease } \\ \text { Akt } & \text { Protein kinase B/serine/threonine kinase } \\ \text { AML } & \text { Acute myeloid leukemia } \\ \text { ARF6 } & \text { ADP-ribosylation factor 6 } \\ \text { ATP } & \text { Adenosine triphosphate } \\ \text { BDNF } & \text { Brain-derived neurotrophic factor } \\ \text { BMP } & \text { Bone morphogenetic protein } \\ \text { BMSC } & \text { Bone marrow stromal cells } \\ \text { CJD } & \text { Creutzfeld-Jakob disease } \\ \text { CLU } & \text { Clusterin } \\ \text { CNS } & \text { Central nervous system } \\ \text { CNTF } & \text { Ciliary neurotrophic factor } \\ \text { Cx43 } & \text { Connexin 43 } \\ \text { EGFP } & \text { Enhanced green fluorescent protein } \\ \text { EGFR } & \text { Epidermal growth factor receptor } \\ \text { EHD1 } & \text { EH domain containing 1 } \\ \text { Eps8 } & \text { Epidermal growth factor receptor pathway } 8 \\ \text { ER } & \text { Endoplasmic reticulum } \\ \text { ERp29 } & \text { Endoplasmic reticulum protein } 29 \\ \text { EV } & \text { Extracellular vesicle } \\ \text { FGF2 } & \text { Fibroblast growth factor } 2 \\ \text { GABA } & \text { Gamma-aminobutyric acid } \\ \end{array}$




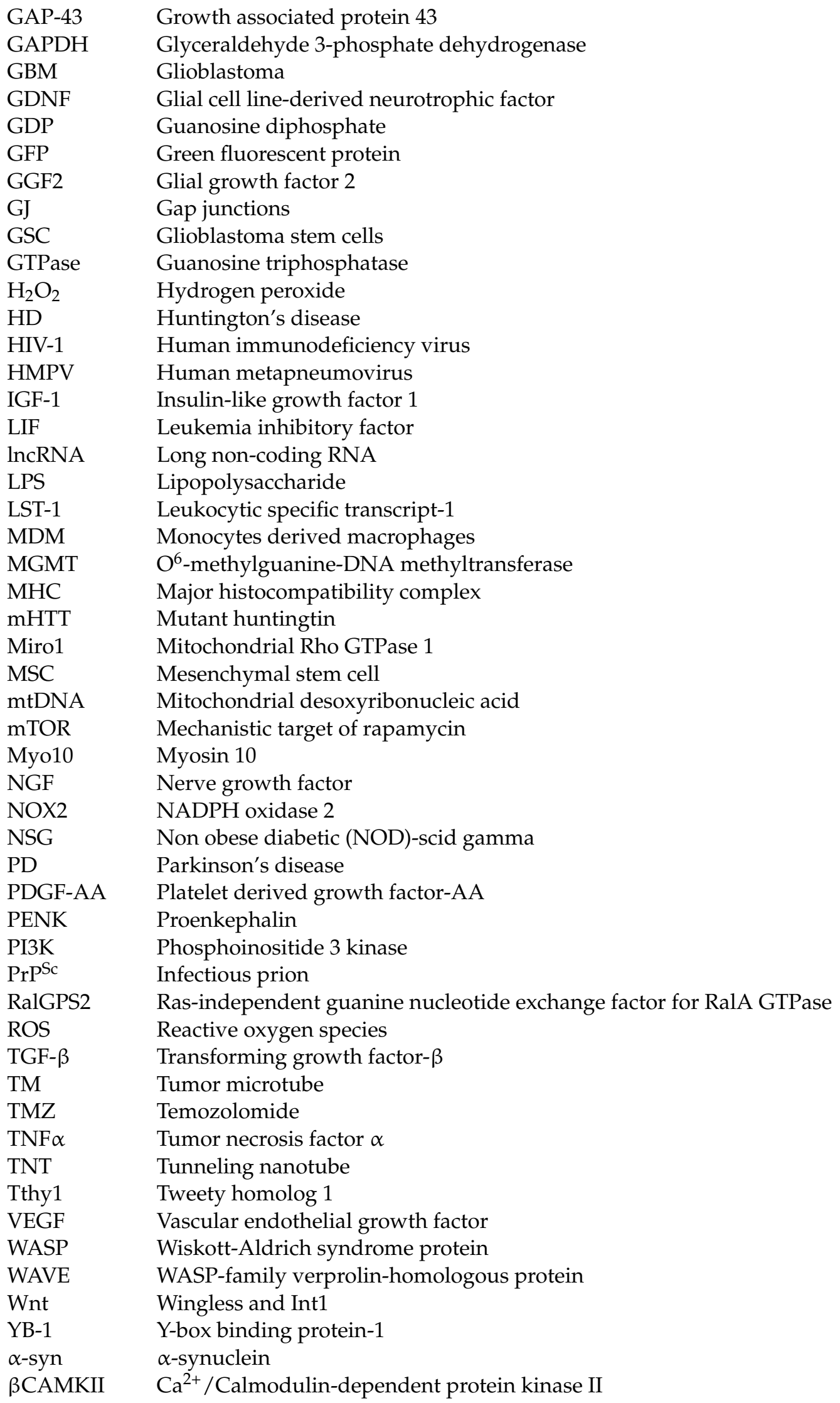




\section{References}

1. Önfelt, B.; Nedvetzki, S.; Yanagi, K.; Davis, D.M. Cutting Edge: Membrane Nanotubes Connect Immune Cells. J. Immunol. 2004, 173, 1511-1513. [CrossRef]

2. Rustom, A.; Saffrich, R.; Markovic, I.; Walther, P.; Gerdes, H.-H. Nanotubular Highways for Intercellular Organelle Transport. Science 2004, 303, 1007-1010. [CrossRef] [PubMed]

3. Baker, M. How the Internet of Cells Has Biologists Buzzing. Nat. News 2017, 549, 322. [CrossRef] [PubMed]

4. Ariazi, J.; Benowitz, A.; De Biasi, V.; Den Boer, M.L.; Cherqui, S.; Cui, H.; Douillet, N.; Eugenin, E.A.; Favre, D.; Goodman, S.; et al. Tunneling Nanotubes and Gap Junctions-Their Role in Long-Range Intercellular Communication during Development, Health, and Disease Conditions. Front. Mol. Neurosci. 2017, 10, 333. [CrossRef] [PubMed]

5. Cordero Cervantes, D.; Zurzolo, C. Peering into Tunneling Nanotubes-The Path Forward. EMBO J. 2021, 40, e105789. [CrossRef] [PubMed]

6. Dong, L.; Gopalan, V.; Holland, O.; Neuzil, J. Mitocans Revisited: Mitochondrial Targeting as Efficient Anti-Cancer Therapy. Int. J. Mol. Sci. 2020, 21, 7941. [CrossRef] [PubMed]

7. Griessinger, E.; Moschoi, R.; Biondani, G.; Peyron, J.-F. Mitochondrial Transfer in the Leukemia Microenvironment. Trends Cancer 2017, 3, 828-839. [CrossRef]

8. Hekmatshoar, Y.; Nakhle, J.; Galloni, M.; Vignais, M.-L. The Role of Metabolism and Tunneling Nanotube-Mediated Intercellular Mitochondria Exchange in Cancer Drug Resistance. Biochem. J. 2018, 475, 2305-2328. [CrossRef]

9. Ljubojevic, N.; Henderson, J.M.; Zurzolo, C. The Ways of Actin: Why Tunneling Nanotubes Are Unique Cell Protrusions. Trends Cell Biol. 2021, 31, 130-142. [CrossRef]

10. Lou, E. A Ticket to Ride: The Implications of Direct Intercellular Communication via Tunneling Nanotubes in Peritoneal and Other Invasive Malignancies. Front. Oncol. 2020, 10, 559548. [CrossRef]

11. Matejka, N.; Reindl, J. Perspectives of Cellular Communication through Tunneling Nanotubes in Cancer Cells and the Connection to Radiation Effects. Radiat. Oncol. 2019, 14, 218. [CrossRef] [PubMed]

12. Nakhle, J.; Rodriguez, A.-M.; Vignais, M.-L. Multifaceted Roles of Mitochondrial Components and Metabolites in Metabolic Diseases and Cancer. Int. J. Mol. Sci. 2020, 21, 4405. [CrossRef] [PubMed]

13. Pinto, G.; Brou, C.; Zurzolo, C. Tunneling Nanotubes: The Fuel of Tumor Progression? Trends Cancer 2020, 6, 874-888. [CrossRef] [PubMed]

14. Rodriguez, A.-M.; Nakhle, J.; Griessinger, E.; Vignais, M.-L. Intercellular Mitochondria Trafficking Highlighting the Dual Role of Mesenchymal Stem Cells as Both Sensors and Rescuers of Tissue Injury. Cell Cycle 2018, 17, 712-721. [CrossRef]

15. Valdebenito, S.; Lou, E.; Baldoni, J.; Okafo, G.; Eugenin, E. The Novel Roles of Connexin Channels and Tunneling Nanotubes in Cancer Pathogenesis. Int. J. Mol. Sci. 2018, 19, 1270. [CrossRef]

16. Zurzolo, C. Tunneling Nanotubes: Reshaping Connectivity. Curr. Opin. Cell Biol. 2021, 71, 139-147. [CrossRef]

17. Lou, E.; Gholami, S.; Romin, Y.; Thayanithy, V.; Fujisawa, S.; Desir, S.; Steer, C.J.; Subramanian, S.; Fong, Y.; Manova-Todorova, K.; et al. Imaging Tunneling Membrane Tubes Elucidates Cell Communication in Tumors. Trends Cancer 2017, 3, 678-685. [CrossRef]

18. Jansen, A.H.P.; Batenburg, K.L.; Pecho-Vrieseling, E.; Reits, E.A. Visualization of Prion-like Transfer in Huntington's Disease Models. Biochim. Biophys. Acta BBA Mol. Basis Dis. 2017, 1863, 793-800. [CrossRef]

19. Jucker, M.; Walker, L.C. Propagation and Spread of Pathogenic Protein Assemblies in Neurodegenerative Diseases. Nat. Neurosci. 2018, 21, 1341-1349. [CrossRef]

20. Sorrentino, Z.A.; Giasson, B.I.; Chakrabarty, P. $\alpha$-Synuclein and Astrocytes: Tracing the Pathways from Homeostasis to Neurodegeneration in Lewy Body Disease. Acta Neuropathol. 2019, 138, 1-21. [CrossRef]

21. Sartori-Rupp, A.; Cordero Cervantes, D.; Pepe, A.; Gousset, K.; Delage, E.; Corroyer-Dulmont, S.; Schmitt, C.; Krijnse-Locker, J.; Zurzolo, C. Correlative Cryo-Electron Microscopy Reveals the Structure of TNTs in Neuronal Cells. Nat. Commun. 2019, 10, 342. [CrossRef] [PubMed]

22. Jung, E.; Osswald, M.; Blaes, J.; Wiestler, B.; Sahm, F.; Schmenger, T.; Solecki, G.; Deumelandt, K.; Kurz, F.T.; Xie, R.; et al. Tweety-Homolog 1 Drives Brain Colonization of Gliomas. J. Neurosci. 2017, 37, 6837-6850. [CrossRef] [PubMed]

23. Jung, E.; Osswald, M.; Ratliff, M.; Dogan, H.; Xie, R.; Weil, S.; Hoffmann, D.C.; Kurz, F.T.; Kessler, T.; Heiland, S.; et al. Tumor Cell Plasticity, Heterogeneity, and Resistance in Crucial Microenvironmental Niches in Glioma. Nat. Commun. 2021, $12,1014$. [CrossRef]

24. Linkous, A.; Balamatsias, D.; Snuderl, M.; Edwards, L.; Miyaguchi, K.; Milner, T.; Reich, B.; Cohen-Gould, L.; Storaska, A.; Nakayama, Y.; et al. Modeling Patient-Derived Glioblastoma with Cerebral Organoids. Cell Rep. 2019, 26, 3203-3211.e5. [CrossRef] [PubMed]

25. Osswald, M.; Jung, E.; Sahm, F.; Solecki, G.; Venkataramani, V.; Blaes, J.; Weil, S.; Horstmann, H.; Wiestler, B.; Syed, M.; et al. Brain Tumour Cells Interconnect to a Functional and Resistant Network. Nature 2015, 528, 93-98. [CrossRef] [PubMed]

26. Osswald, M.; Jung, E.; Wick, W.; Winkler, F. Tunneling Nanotube-like Structures in Brain Tumors. Cancer Rep. 2019,2 , e1181. [CrossRef]

27. Pinto, G.; Saenz-de-Santa-Maria, I.; Chastagner, P.; Perthame, E.; Delmas, C.; Toulas, C.; Moyal-Jonathan-Cohen, E.; Brou, C.; Zurzolo, C. Patient-Derived Glioblastoma Stem Cells Transfer Mitochondria through Tunneling Nanotubes in Tumor Organoids. Biochem. J. 2021, 478, 21-39. [CrossRef] [PubMed] 
28. Winkler, F.; Wick, W. Harmful Networks in the Brain and Beyond. Science 2018, 359, 1100-1101. [CrossRef]

29. Xie, R.; Kessler, T.; Grosch, J.; Hai, L.; Venkataramani, V.; Huang, L.; Hoffmann, D.C.; Solecki, G.; Ratliff, M.; Schlesner, M.; et al. Tumor Cell Network Integration in Glioma Represents a Stemness Feature. Neuro-Oncology 2021, 23, 757-769. [CrossRef]

30. Azorín, D.D.; Winkler, F. Two Routes of Direct Intercellular Communication in Brain Cancer. Biochem. J. 2021, 478, 1283-1286. [CrossRef]

31. Chinnery, H.R.; Pearlman, E.; McMenamin, P.G. Cutting Edge: Membrane Nanotubes In Vivo: A Feature of MHC Class II+ Cells in the Mouse Cornea. J. Immunol. 2008, 180, 5779. [CrossRef] [PubMed]

32. Lou, E.; Fujisawa, S.; Morozov, A.; Barlas, A.; Romin, Y.; Dogan, Y.; Gholami, S.; Moreira, A.L.; Manova-Todorova, K.; Moore, M.A.S. Tunneling Nanotubes Provide a Unique Conduit for Intercellular Transfer of Cellular Contents in Human Malignant Pleural Mesothelioma. PLoS ONE 2012, 7, e33093. [CrossRef] [PubMed]

33. Desir, S.; O’Hare, P.; Vogel, R.I.; Sperduto, W.; Sarkari, A.; Dickson, E.L.; Wong, P.; Nelson, A.C.; Fong, Y.; Steer, C.J.; et al. Chemotherapy-Induced Tunneling Nanotubes Mediate Intercellular Drug Efflux in Pancreatic Cancer. Sci. Rep. 2018, 8, 9484. [CrossRef]

34. Civita, P.; M. Leite, D.; Pilkington, G.J. Pre-Clinical Drug Testing in 2D and 3D Human In Vitro Models of Glioblastoma Incorporating Non-Neoplastic Astrocytes: Tunneling Nano Tubules and Mitochondrial Transfer Modulates Cell Behavior and Therapeutic Respons. Int. J. Mol. Sci. 2019, 20, 6017. [CrossRef]

35. Tan, H.-Y.; Cho, H.; Lee, L.P. Human Mini-Brain Models. Nat. Biomed. Eng. 2021, 5, 11-25. [CrossRef] [PubMed]

36. Yi, H.-G.; Jeong, Y.H.; Kim, Y.; Choi, Y.-J.; Moon, H.E.; Park, S.H.; Kang, K.S.; Bae, M.; Jang, J.; Youn, H.; et al. A Bioprinted Human-Glioblastoma-on-a-Chip for the Identification of Patient-Specific Responses to Chemoradiotherapy. Nat. Biomed. Eng. 2019, 3, 509-519. [CrossRef]

37. Heinrich, M.A.; Bansal, R.; Lammers, T.; Zhang, Y.S.; Michel Schiffelers, R.; Prakash, J. 3D-Bioprinted Mini-Brain: A Glioblastoma Model to Study Cellular Interactions and Therapeutics. Adv. Mater. 2019, 31, e1806590. [CrossRef]

38. Govindan, S.; Batti, L.; Osterop, S.F.; Stoppini, L.; Roux, A. Mass Generation, Neuron Labeling, and 3D Imaging of Minibrains. Front. Bioeng. Biotechnol. 2021, 8, 1436. [CrossRef]

39. Ahmad, T.; Mukherjee, S.; Pattnaik, B.; Kumar, M.; Singh, S.; Kumar, M.; Rehman, R.; Tiwari, B.K.; Jha, K.A.; Barhanpurkar, A.P.; et al. Miro1 Regulates Intercellular Mitochondrial Transport \& Enhances Mesenchymal Stem Cell Rescue Efficacy. EMBO J. 2014, 33, 994-1010. [CrossRef]

40. Islam, M.N.; Das, S.R.; Emin, M.T.; Wei, M.; Sun, L.; Westphalen, K.; Rowlands, D.J.; Quadri, S.K.; Bhattacharya, S.; Bhattacharya, J. Mitochondrial Transfer from Bone-Marrow-Derived Stromal Cells to Pulmonary Alveoli Protects against Acute Lung Injury. Nat. Med. 2012, 18, 759-765. [CrossRef]

41. Dong, L.-F.; Kovarova, J.; Bajzikova, M.; Bezawork-Geleta, A.; Svec, D.; Endaya, B.; Sachaphibulkij, K.; Coelho, A.R.; Sebkova, N.; Ruzickova, A.; et al. Horizontal Transfer of Whole Mitochondria Restores Tumorigenic Potential in Mitochondrial DNA-Deficient Cancer Cells. eLife 2017, 6, e22187. [CrossRef] [PubMed]

42. Wang, Z.; McCracken, S.; Williams, P.R. Transpupillary Two-Photon In Vivo Imaging of the Mouse Retina. J. Vis. Exp. 2021, 13, e61970. [CrossRef] [PubMed]

43. Alarcon-Martinez, L.; Villafranca-Baughman, D.; Quintero, H.; Kacerovsky, J.B.; Dotigny, F.; Murai, K.K.; Prat, A.; Drapeau, P.; Di Polo, A. Interpericyte Tunnelling Nanotubes Regulate Neurovascular Coupling. Nature 2020, 585, 91-95. [CrossRef] [PubMed]

44. Ortin-Martinez, A.; Yan, N.E.; Tsai, E.L.S.; Comanita, L.; Gurdita, A.; Tachibana, N.; Liu, Z.C.; Lu, S.; Dolati, P.; Pokrajac, N.T.; et al. Photoreceptor Nanotubes Mediate the in Vivo Exchange of Intracellular Material. EMBO J. 2021, 40, e107264. [CrossRef]

45. Kalargyrou, A.A.; Basche, M.; Hare, A.; West, E.L.; Smith, A.J.; Ali, R.R.; Pearson, R.A. Nanotube-like Processes Facilitate Material Transfer between Photoreceptors. EMBO Rep. 2021, 22, e53732. [CrossRef]

46. Chen, J.; Cao, J. Astrocyte-to-Neuron Transportation of Enhanced Green Fluorescent Protein in Cerebral Cortex Requires F-Actin Dependent Tunneling Nanotubes. Sci. Rep. 2021, 11, 16798. [CrossRef]

47. Weil, S.; Osswald, M.; Solecki, G.; Grosch, J.; Jung, E.; Lemke, D.; Ratliff, M.; Hänggi, D.; Wick, W.; Winkler, F. Tumor Microtubes Convey Resistance to Surgical Lesions and Chemotherapy in Gliomas. Neuro-Oncology 2017, 19, 1316-1326. [CrossRef]

48. Moschoi, R.; Imbert, V.; Nebout, M.; Chiche, J.; Mary, D.; Prebet, T.; Saland, E.; Castellano, R.; Pouyet, L.; Collette, Y.; et al. Protective Mitochondrial Transfer from Bone Marrow Stromal Cells to Acute Myeloid Leukemic Cells during Chemotherapy. Blood 2016, 128, 253-264. [CrossRef] [PubMed]

49. Hanna, S.J.; McCoy-Simandle, K.; Miskolci, V.; Guo, P.; Cammer, M.; Hodgson, L.; Cox, D. The Role of Rho-GTPases and Actin Polymerization during Macrophage Tunneling Nanotube Biogenesis. Sci. Rep. 2017, 7, 8547. [CrossRef]

50. Hase, K.; Kimura, S.; Takatsu, H.; Ohmae, M.; Kawano, S.; Kitamura, H.; Ito, M.; Watarai, H.; Hazelett, C.C.; Yeaman, C.; et al. M-Sec Promotes Membrane Nanotube Formation by Interacting with Ral and the Exocyst Complex. Nat. Cell Biol. 2009, 11, 1427-1432. [CrossRef]

51. Pergu, R.; Dagar, S.; Kumar, H.; Kumar, R.; Bhattacharya, J.; Mylavarapu, S.V.S. The Chaperone ERp29 Is Required for Tunneling Nanotube Formation by Stabilizing MSec. J. Biol. Chem. 2019, 294, 7177-7193. [CrossRef] [PubMed]

52. Schiller, C.; Diakopoulos, K.N.; Rohwedder, I.; Kremmer, E.; von Toerne, C.; Ueffing, M.; Weidle, U.H.; Ohno, H.; Weiss, E.H. LST1 Promotes the Assembly of a Molecular Machinery Responsible for Tunneling Nanotube Formation. J. Cell Sci. 2013, 126, 767-777. [CrossRef] [PubMed] 
53. D'Aloia, A.; Arrigoni, E.; Costa, B.; Berruti, G.; Martegani, E.; Sacco, E.; Ceriani, M. RalGPS2 Interacts with Akt and PDK1 Promoting Tunneling Nanotubes Formation in Bladder Cancer and Kidney Cells Microenvironment. Cancers 2021, $13,6330$. [CrossRef]

54. Saha, T.; Dash, C.; Jayabalan, R.; Khiste, S.; Kulkarni, A.; Kurmi, K.; Mondal, J.; Majumder, P.K.; Bardia, A.; Jang, H.L.; et al. Intercellular Nanotubes Mediate Mitochondrial Trafficking between Cancer and Immune Cells. Nat. Nanotechnol. 2022, 17, 98-106. [CrossRef] [PubMed]

55. Kretschmer, A.; Zhang, F.; Somasekharan, S.P.; Tse, C.; Leachman, L.; Gleave, A.; Li, B.; Asmaro, I.; Huang, T.; Kotula, L.; et al Stress-Induced Tunneling Nanotubes Support Treatment Adaptation in Prostate Cancer. Sci. Rep. 2019, 9, 7826. [CrossRef]

56. Delage, E.; Cervantes, D.C.; Pénard, E.; Schmitt, C.; Syan, S.; Disanza, A.; Scita, G.; Zurzolo, C. Differential Identity of Filopodia and Tunneling Nanotubes Revealed by the Opposite Functions of Actin Regulatory Complexes. Sci. Rep. 2016, 6, 39632. [CrossRef]

57. Gousset, K.; Marzo, L.; Commere, P.-H.; Zurzolo, C. Myo10 Is a Key Regulator of TNT Formation in Neuronal Cells. J. Cell Sci. 2013, 126, 4424-4435. [CrossRef]

58. Wang, Y.; Cui, J.; Sun, X.; Zhang, Y. Tunneling-Nanotube Development in Astrocytes Depends on P53 Activation. Cell Death Differ. 2011, 18, 732-742. [CrossRef]

59. Vargas, J.Y.; Loria, F.; Wu, Y.-J.; Córdova, G.; Nonaka, T.; Bellow, S.; Syan, S.; Hasegawa, M.; van Woerden, G.M.; Trollet, C.; et al. The Wnt/ $\mathrm{Ca}^{2+}$ Pathway Is Involved in Interneuronal Communication Mediated by Tunneling Nanotubes. EMBO J. 2019, 38, e101230. [CrossRef]

60. Bhat, S.; Ljubojevic, N.; Zhu, S.; Fukuda, M.; Echard, A.; Zurzolo, C. Rab35 and Its Effectors Promote Formation of Tunneling Nanotubes in Neuronal Cells. Sci. Rep. 2020, 10, 16803. [CrossRef]

61. Ribeiro-Rodrigues, T.M.; Martins-Marques, T.; Morel, S.; Kwak, B.R.; Girão, H. Role of Connexin 43 in Different Forms of Intercellular Communication-Gap Junctions, Extracellular Vesicles and Tunnelling Nanotubes. J. Cell Sci. 2017, 130, 3619-3630. [CrossRef] [PubMed]

62. Wang, J.; Yang, Z.-Y.; Guo, Y.-F.; Kuang, J.-Y.; Bian, X.-W.; Yu, S.-C. Targeting Different Domains of Gap Junction Protein to Control Malignant Glioma. Neuro-Oncology 2018, 20, 885-896. [CrossRef] [PubMed]

63. Marlein, C.R.; Piddock, R.E.; Mistry, J.J.; Zaitseva, L.; Hellmich, C.; Horton, R.H.; Zhou, Z.; Auger, M.J.; Bowles, K.M.; Rushworth, S.A. CD38-Driven Mitochondrial Trafficking Promotes Bioenergetic Plasticity in Multiple Myeloma. Cancer Res. 2019, 79, 2285-2297. [CrossRef]

64. Rustom, A. The Missing Link: Does Tunnelling Nanotube-Based Supercellularity Provide a New Understanding of Chronic and Lifestyle Diseases? Open Biol. 2016, 6, 160057. [CrossRef] [PubMed]

65. Zhang, L.; Zhang, Y. Tunneling Nanotubes between Rat Primary Astrocytes and C6 Glioma Cells Alter Proliferation Potential of Glioma Cells. Neurosci. Bull. 2015, 31, 371-378. [CrossRef]

66. Zhu, D.; Tan, K.S.; Zhang, X.; Sun, A.Y.; Sun, G.Y.; Lee, J.C.-M. Hydrogen Peroxide Alters Membrane and Cytoskeleton Properties and Increases Intercellular Connections in Astrocytes. J. Cell Sci. 2005, 118, 3695-3703. [CrossRef]

67. Marlein, C.R.; Zaitseva, L.; Piddock, R.E.; Robinson, S.; Edwards, D.; Shafat, M.S.; Zhou, Z.; Lawes, M.; Bowles, K.M.; Rushworth, S.A. NADPH Oxidase-2 Derived Superoxide Drives Mitochondrial Transfer from Bone Marrow Stromal Cells to Leukemic Blasts Blood 2017, 130, 1649-1660, blood-2017-03-772939. [CrossRef]

68. Matejka, N.; Reindl, J. Influence of $\alpha$-Particle Radiation on Intercellular Communication Networks of Tunneling Nanotubes in U87 Glioblastoma Cells. Front. Oncol. 2020, 10, 1691. [CrossRef]

69. Valdebenito, S.; Audia, A.; Bhat, K.P.L.; Okafo, G.; Eugenin, E.A. Tunneling Nanotubes Mediate Adaptation of Glioblastoma Cells to Temozolomide and Ionizing Radiation Treatment. iScience 2020, 23, 101450. [CrossRef]

70. Hashimoto, M.; Bhuyan, F.; Hiyoshi, M.; Noyori, O.; Nasser, H.; Miyazaki, M.; Saito, T.; Kondoh, Y.; Osada, H.; Kimura, S.; et al. Potential Role of the Formation of Tunneling Nanotubes in HIV-1 Spread in Macrophages. J. Immunol. 2016, 196, $1832-1841$. [CrossRef]

71. El Najjar, F.; Cifuentes-Muñoz, N.; Chen, J.; Zhu, H.; Buchholz, U.J.; Moncman, C.L.; Dutch, R.E. Human Metapneumovirus Induces Reorganization of the Actin Cytoskeleton for Direct Cell-to-Cell Spread. PLoS Pathog. 2016, 12, e1005922. [CrossRef]

72. Jansens, R.J.J.; Van den Broeck, W.; De Pelsmaeker, S.; Lamote, J.A.S.; Van Waesberghe, C.; Couck, L.; Favoreel, H.W. Pseudorabies Virus US3-Induced Tunneling Nanotubes Contain Stabilized Microtubules, Interact with Neighboring Cells via Cadherins, and Allow Intercellular Molecular Communication. J. Virol. 2017, 91, e00749-17. [CrossRef] [PubMed]

73. Abounit, S.; Wu, J.W.; Duff, K.; Victoria, G.S.; Zurzolo, C. Tunneling Nanotubes: A Possible Highway in the Spreading of Tau and Other Prion-like Proteins in Neurodegenerative Diseases. Prion 2016, 10, 344-351. [CrossRef] [PubMed]

74. Abounit, S.; Bousset, L.; Loria, F.; Zhu, S.; de Chaumont, F.; Pieri, L.; Olivo-Marin, J.-C.; Melki, R.; Zurzolo, C. Tunneling Nanotubes Spread Fibrillar $\alpha$-Synuclein by Intercellular Trafficking of Lysosomes. EMBO J. 2016, 35, 2120-2138. [CrossRef] [PubMed]

75. Costanzo, M.; Abounit, S.; Marzo, L.; Danckaert, A.; Chamoun, Z.; Roux, P.; Zurzolo, C. Transfer of Polyglutamine Aggregates in Neuronal Cells Occurs in Tunneling Nanotubes. J. Cell Sci. 2013, 126, 3678-3685. [CrossRef] [PubMed]

76. Tardivel, M.; Bégard, S.; Bousset, L.; Dujardin, S.; Coens, A.; Melki, R.; Buée, L.; Colin, M. Tunneling Nanotube (TNT)-Mediated Neuron-to Neuron Transfer of Pathological Tau Protein Assemblies. Acta Neuropathol. Commun. 2016, 4, 117. [CrossRef]

77. Zhu, S.; Victoria, G.S.; Marzo, L.; Ghosh, R.; Zurzolo, C. Prion Aggregates Transfer through Tunneling Nanotubes in Endocytic Vesicles. Prion 2015, 9, 125-135. [CrossRef] 
78. Konno, T.; Melo, E.P.; Chambers, J.E.; Avezov, E. Intracellular Sources of ROS/H2O2 in Health and Neurodegeneration: Spotlight on Endoplasmic Reticulum. Cells 2021, 10, 233. [CrossRef]

79. Lee, Y.M.; He, W.; Liou, Y.-C. The Redox Language in Neurodegenerative Diseases: Oxidative Post-Translational Modifications by Hydrogen Peroxide. Cell Death Dis. 2021, 12, 58. [CrossRef]

80. Cihankaya, H.; Theiss, C.; Matschke, V. Significance of Intercellular Communication for Neurodegenerative Diseases. Neural Regen. Res. 2022, 17, 1015-1017. [CrossRef]

81. Kiray, H.; Lindsay, S.L.; Hosseinzadeh, S.; Barnett, S.C. The Multifaceted Role of Astrocytes in Regulating Myelination. Exp. Neurol. 2016, 283, 541-549. [CrossRef] [PubMed]

82. Shanmughapriya, S.; Langford, D.; Natarajaseenivasan, K. Inter and Intracellular Mitochondrial Trafficking in Health and Disease. Ageing Res. Rev. 2020, 62, 101128. [CrossRef] [PubMed]

83. Abbott, G.W. Chansporter Complexes in Cell Signaling. FEBS Lett. 2017, 591, 2556-2576. [CrossRef] [PubMed]

84. Chang, M.-Y.; Son, H.; Lee, Y.-S.; Lee, S.-H. Neurons and Astrocytes Secrete Factors That Cause Stem Cells to Differentiate into Neurons and Astrocytes, Respectively. Mol. Cell Neurosci. 2003, 23, 414-426. [CrossRef]

85. Cohen, S.; Liu, Q.; Wright, M.; Garvin, J.; Rarick, K.; Harder, D. High Glucose Conditioned Neonatal Astrocytes Results in Impaired Mitogenic Activity in Cerebral Microvessel Endothelial Cells in Co-Culture. Heliyon 2019, 5, e01795. [CrossRef]

86. Liddelow, S.A.; Barres, B.A. Reactive Astrocytes: Production, Function, and Therapeutic Potential. Immunity 2017, 46, 957-967. [CrossRef]

87. Matejuk, A.; Ransohoff, R.M. Crosstalk Between Astrocytes and Microglia: An Overview. Front. Immunol. 2020, 11, 1416. [CrossRef]

88. Nutma, E.; van Gent, D.; Amor, S.; Peferoen, L.A.N. Astrocyte and Oligodendrocyte Cross-Talk in the Central Nervous System Cells 2020, 9, 600. [CrossRef]

89. Wu, H.; Friedman, W.J.; Dreyfus, C.F. Differential Regulation of Neurotrophin Expression in Basal Forebrain Astrocytes by Neuronal Signals. J. Neurosci. Res. 2004, 76, 76-85. [CrossRef]

90. Ishitsuka, K.; Ago, T.; Arimura, K.; Nakamura, K.; Tokami, H.; Makihara, N.; Kuroda, J.; Kamouchi, M.; Kitazono, T. Neurotrophin Production in Brain Pericytes during Hypoxia: A Role of Pericytes for Neuroprotection. Microvasc. Res. 2012, 83, 352-359. [CrossRef]

91. Gomes, F.C.; Spohr, T.C.; Martinez, R.; Moura Neto, V. Cross-Talk between Neurons and Glia: Highlights on Soluble Factors. Braz. J. Med. Biol. Res. 2001, 34, 611-620. [CrossRef] [PubMed]

92. Jang, M.; Gould, E.; Xu, J.; Kim, E.J.; Kim, J.H. Oligodendrocytes Regulate Presynaptic Properties and Neurotransmission through BDNF Signaling in the Mouse Brainstem. eLife 2019, 8, e42156. [CrossRef] [PubMed]

93. Wang, D.D.; Bordey, A. The Astrocyte Odyssey. Prog. Neurobiol. 2008, 86, 342-367. [CrossRef] [PubMed]

94. Flores, K.R.; Viccaro, F.; Aquilini, M.; Scarpino, S.; Ronchetti, F.; Mancini, R.; Di Napoli, A.; Scozzi, D.; Ricci, A. Protective Role of Brain Derived Neurotrophic Factor (BDNF) in Obstructive Sleep Apnea Syndrome (OSAS) Patients. PLoS ONE 2020, 15, e0227834. [CrossRef]

95. Thored, P.; Heldmann, U.; Gomes-Leal, W.; Gisler, R.; Darsalia, V.; Taneera, J.; Nygren, J.M.; Jacobsen, S.-E.W.; Ekdahl, C.T.; Kokaia, Z.; et al. Long-Term Accumulation of Microglia with Proneurogenic Phenotype Concomitant with Persistent Neurogenesis in Adult Subventricular Zone after Stroke. Glia 2009, 57, 835-849. [CrossRef]

96. Battista, D.; Ferrari, C.C.; Gage, F.H.; Pitossi, F.J. Neurogenic Niche Modulation by Activated Microglia: Transforming Growth Factor Beta Increases Neurogenesis in the Adult Dentate Gyrus. Eur. J. Neurosci. 2006, 23, 83-93. [CrossRef]

97. Li, Q.; Barres, B.A. Microglia and Macrophages in Brain Homeostasis and Disease. Nat. Rev. Immunol. 2018, 18, 225-242. [CrossRef]

98. Verkhratsky, A.; Matteoli, M.; Parpura, V.; Mothet, J.-P.; Zorec, R. Astrocytes as Secretory Cells of the Central Nervous System: Idiosyncrasies of Vesicular Secretion. EMBO J. 2016, 35, 239-257. [CrossRef]

99. Schiera, G.; Di Liegro, C.M.; Di Liegro, I. Cell-to-Cell Communication in Learning and Memory: From Neuro- and GlioTransmission to Information Exchange Mediated by Extracellular Vesicles. Int. J. Mol. Sci. 2019, 21, 266. [CrossRef]

100. Paolicelli, R.C.; Bergamini, G.; Rajendran, L. Cell-to-Cell Communication by Extracellular Vesicles: Focus on Microglia. Neuroscience 2019, 405, 148-157. [CrossRef]

101. Gabrielli, M.; Battista, N.; Riganti, L.; Prada, I.; Antonucci, F.; Cantone, L.; Matteoli, M.; Maccarrone, M.; Verderio, C. Active Endocannabinoids Are Secreted on Extracellular Membrane Vesicles. EMBO Rep. 2015, 16, 213-220. [CrossRef] [PubMed]

102. Antonucci, F.; Turola, E.; Riganti, L.; Caleo, M.; Gabrielli, M.; Perrotta, C.; Novellino, L.; Clementi, E.; Giussani, P.; Viani, P.; et al. Microvesicles Released from Microglia Stimulate Synaptic Activity via Enhanced Sphingolipid Metabolism. EMBO J. 2012, 31 , 1231-1240. [CrossRef] [PubMed]

103. Datta Chaudhuri, A.; Dasgheyb, R.M.; DeVine, L.R.; Bi, H.; Cole, R.N.; Haughey, N.J. Stimulus-Dependent Modifications in Astrocyte-Derived Extracellular Vesicle Cargo Regulate Neuronal Excitability. Glia 2020, 68, 128-144. [CrossRef] [PubMed]

104. Xu, L.; Cao, H.; Xie, Y.; Zhang, Y.; Du, M.; Xu, X.; Ye, R.; Liu, X. Exosome-Shuttled MiR-92b-3p from Ischemic Preconditioned Astrocytes Protects Neurons against Oxygen and Glucose Deprivation. Brain Res. 2019, 1717, 66-73. [CrossRef] [PubMed]

105. Jiang, D.; Gong, F.; Ge, X.; Lv, C.; Huang, C.; Feng, S.; Zhou, Z.; Rong, Y.; Wang, J.; Ji, C.; et al. Neuron-Derived ExosomesTransmitted MiR-124-3p Protect Traumatically Injured Spinal Cord by Suppressing the Activation of Neurotoxic Microglia and Astrocytes. J. Nanobiotechnol. 2020, 18, 105. [CrossRef] 
106. Nualart-Marti, A.; Solsona, C.; Fields, R.D. Gap Junction Communication in Myelinating Glia. Biochim. Biophys. Acta 2013, 1828, 69-78. [CrossRef]

107. Liang, Z.; Wang, X.; Hao, Y.; Qiu, L.; Lou, Y.; Zhang, Y.; Ma, D.; Feng, J. The Multifaceted Role of Astrocyte Connexin 43 in Ischemic Stroke Through Forming Hemichannels and Gap Junctions. Front. Neurol. 2020, 11, 703. [CrossRef]

108. Basu, R.; Sarma, J.D. Connexin 43/47 Channels Are Important for Astrocyte/Oligodendrocyte Cross-Talk in Myelination and Demyelination. J. Biosci. 2018, 43, 1055-1068. [CrossRef]

109. Ezan, P.; André, P.; Cisternino, S.; Saubaméa, B.; Boulay, A.-C.; Doutremer, S.; Thomas, M.-A.; Quenech'du, N.; Giaume, C.; Cohen-Salmon, M. Deletion of Astroglial Connexins Weakens the Blood-Brain Barrier. J. Cereb. Blood Flow Metab. 2012, 32, 1457-1467. [CrossRef]

110. Pereda, A.E. Neurobiology: All Synapses Are Created Equal. Curr Biol 2015, 25, R38-R41. [CrossRef]

111. Haber, M.; Zhou, L.; Murai, K.K. Cooperative Astrocyte and Dendritic Spine Dynamics at Hippocampal Excitatory Synapses. J. Neurosci. 2006, 26, 8881-8891. [CrossRef] [PubMed]

112. Nishida, H.; Okabe, S. Direct Astrocytic Contacts Regulate Local Maturation of Dendritic Spines. J. Neurosci. 2007, 27, 331-340. [CrossRef] [PubMed]

113. Wang, X.; Bukoreshtliev, N.V.; Gerdes, H.-H. Developing Neurons Form Transient Nanotubes Facilitating Electrical Coupling and Calcium Signaling with Distant Astrocytes. PLoS ONE 2012, 7, e47429. [CrossRef] [PubMed]

114. Spitzer, N.C. Electrical Activity in Early Neuronal Development. Nature 2006, 444, 707-712. [CrossRef] [PubMed]

115. Errede, M.; Mangieri, D.; Longo, G.; Girolamo, F.; de Trizio, I.; Vimercati, A.; Serio, G.; Frei, K.; Perris, R.; Virgintino, D. Tunneling Nanotubes Evoke Pericyte/Endothelial Communication during Normal and Tumoral Angiogenesis. Fluids Barriers CNS 2018, 15, 28. [CrossRef] [PubMed]

116. Rostami, J.; Mothes, T.; Kolahdouzan, M.; Eriksson, O.; Moslem, M.; Bergström, J.; Ingelsson, M.; O'Callaghan, P.; Healy, L.M.; Falk, A.; et al. Crosstalk between Astrocytes and Microglia Results in Increased Degradation of $\alpha$-Synuclein and Amyloid- $\beta$ Aggregates. J. Neuroinflamm. 2021, 18, 124. [CrossRef]

117. Scheiblich, H.; Dansokho, C.; Mercan, D.; Schmidt, S.V.; Bousset, L.; Wischhof, L.; Eikens, F.; Odainic, A.; Spitzer, J.; Griep, A.; et al. Microglia Jointly Degrade Fibrillar Alpha-Synuclein Cargo by Distribution through Tunneling Nanotubes. Cell 2021, 184, 5089-5106.e21. [CrossRef]

118. Kalogeris, T.; Bao, Y.; Korthuis, R.J. Mitochondrial Reactive Oxygen Species: A Double Edged Sword in Ischemia/Reperfusion vs. Preconditioning. Redox Biol. 2014, 2, 702-714. [CrossRef]

119. Sun, X.; Wang, Y.; Zhang, J.; Tu, J.; Wang, X.-J.; Su, X.-D.; Wang, L.; Zhang, Y. Tunneling-Nanotube Direction Determination in Neurons and Astrocytes. Cell Death Dis. 2012, 3, e438. [CrossRef]

120. Mahrouf-Yorgov, M.; Augeul, L.; Da Silva, C.C.; Jourdan, M.; Rigolet, M.; Manin, S.; Ferrera, R.; Ovize, M.; Henry, A.; Guguin, A.; et al. Mesenchymal Stem Cells Sense Mitochondria Released from Damaged Cells as Danger Signals to Activate Their Rescue Properties. Cell Death Differ. 2017, 24, 1224-1238. [CrossRef]

121. Lippert, T.; Borlongan, C.V. Prophylactic Treatment of Hyperbaric Oxygen Treatment Mitigates Inflammatory Response via Mitochondria Transfer. CNS Neurosci. Ther. 2019, 25, 815-823. [CrossRef] [PubMed]

122. Ren, D.; Zheng, P.; Zou, S.; Gong, Y.; Wang, Y.; Duan, J.; Deng, J.; Chen, H.; Feng, J.; Zhong, C.; et al. GJA1-20K Enhances Mitochondria Transfer from Astrocytes to Neurons via Cx43-TnTs After Traumatic Brain Injury. Cell. Mol. Neurobiol. 2021, 1-9. [CrossRef] [PubMed]

123. Wang, X.; Gerdes, H.-H. Transfer of Mitochondria via Tunneling Nanotubes Rescues Apoptotic PC12 Cells. Cell Death Differ. 2015, 22, 1181-1191. [CrossRef] [PubMed]

124. Wang, X.; Yu, X.; Xie, C.; Tan, Z.; Tian, Q.; Zhu, D.; Liu, M.; Guan, Y. Rescue of Brain Function Using Tunneling Nanotubes Between Neural Stem Cells and Brain Microvascular Endothelial Cells. Mol. Neurobiol. 2016, 53, 2480-2488. [CrossRef] [PubMed]

125. Davis, C.O.; Keun-Young, K.; Bushong, E.A.; Mills, E.A.; Boassa, D.; Shih, T.; Kinebuchi, M.; Phan, S.; Yi, Z.; Bihlmeyer, N.A.; et al. Transcellular Degradation of Axonal Mitochondria. Proc. Natl. Acad. Sci. USA 2014, 111, 9633-9638. [CrossRef]

126. Levoux, J.; Prola, A.; Lafuste, P.; Gervais, M.; Braud, L.; Schirmann, A.; Hersant, B.; Sid-Ahmed, M.; Ben-Larbi, S.; Komrskova, K.; et al. Platelets Promote Pro-Angiogenic Activity of Mesenchymal Stem Cells Via Mitochondrial Transfer and Metabolic Reprogramming; Social Science Research Network: Rochester, NY, USA, 2020.

127. Nimmerjahn, A. Resting Microglial Cells Are Highly Dynamic Surveillants of Brain Parenchyma in Vivo. Science 2005, 308, 1314-1318. [CrossRef]

128. Wake, H.; Moorhouse, A.J.; Jinno, S.; Kohsaka, S.; Nabekura, J. Resting Microglia Directly Monitor the Functional State of Synapses In Vivo and Determine the Fate of Ischemic Terminals. J. Neurosci. 2009, 29, 3974-3980. [CrossRef]

129. Weng, Z.; Zhang, B.; Tsilioni, I.; Theoharides, T.C. Nanotube Formation: A Rapid Form of "Alarm Signaling"? Clin. Ther. 2016, 38, 1066-1072. [CrossRef]

130. Forsythe, P. Mast Cells in Neuroimmune Interactions. Trends Neurosci. 2019, 42, 43-55. [CrossRef]

131. Traina, G. The Role of Mast Cells in the Gut and Brain. J. Integr. Neurosci 2021, 20, 185-196. [CrossRef]

132. Bittins, M.; Wang, X. TNT-Induced Phagocytosis: Tunneling Nanotubes Mediate the Transfer of Pro-Phagocytic Signals From Apoptotic to Viable Cells: Transfer of Ps Via Tnts Induces Phagocytosis. J. Cell. Physiol. 2017, 232, 2271-2279. [CrossRef] [PubMed] 
133. Nasoni, M.G.; Carloni, S.; Canonico, B.; Burattini, S.; Cesarini, E.; Papa, S.; Pagliarini, M.; Ambrogini, P.; Balduini, W.; Luchetti, F. Melatonin Reshapes the Mitochondrial Network and Promotes Intercellular Mitochondrial Transfer via Tunneling Nanotubes after Ischemic-like Injury in Hippocampal HT22 Cells. J. Pineal Res. 2021, 71, e12747. [CrossRef] [PubMed]

134. Yip, H.-K.; Dubey, N.K.; Lin, K.-C.; Sung, P.-H.; Chiang, J.Y.; Chu, Y.-C.; Huang, C.-R.; Chen, Y.-L.; Deng, Y.-H.; Cheng, H.-C.; et al. Melatonin Rescues Cerebral Ischemic Events through Upregulated Tunneling Nanotube-Mediated Mitochondrial Transfer and Downregulated Mitochondrial Oxidative Stress in Rat Brain. Biomed. Pharmacother. 2021, 139, 111593. [CrossRef] [PubMed]

135. Dilna, A.; Deepak, K.V.; Damodaran, N.; Kielkopf, C.S.; Kagedal, K.; Ollinger, K.; Nath, S. Amyloid- $\beta$ Induced Membrane Damage Instigates Tunneling Nanotube-like Conduits by P21-Activated Kinase Dependent Actin Remodulation. Biochim. Biophys. Acta BBA Mol. Basis Dis. 2021, 1867, 166246. [CrossRef]

136. Gousset, K.; Schiff, E.; Langevin, C.; Marijanovic, Z.; Caputo, A.; Browman, D.T.; Chenouard, N.; de Chaumont, F.; Martino, A.; Enninga, J.; et al. Prions Hijack Tunnelling Nanotubes for Intercellular Spread. Nat. Cell Biol. 2009, 11, 328-336. [CrossRef]

137. Sharma, M.; Subramaniam, S. Rhes Travels from Cell to Cell and Transports Huntington Disease Protein via TNT-like Protrusion. J. Cell Biol. 2019, 218, 1972-1993. [CrossRef]

138. Dieriks, B.V.; Park, T.I.-H.; Fourie, C.; Faull, R.L.M.; Dragunow, M.; Curtis, M.A. $\alpha$-Synuclein Transfer through Tunneling Nanotubes Occurs in SH-SY5Y Cells and Primary Brain Pericytes from Parkinson's Disease Patients. Sci. Rep. 2017, 7, 42984. [CrossRef]

139. Rostami, J.; Holmqvist, S.; Lindström, V.; Sigvardson, J.; Westermark, G.T.; Ingelsson, M.; Bergström, J.; Roybon, L.; Erlandsson, A. Human Astrocytes Transfer Aggregated Alpha-Synuclein via Tunneling Nanotubes. J. Neurosci. 2017, 37, 11835-11853. [CrossRef]

140. Valdinocci, D.; Simões, R.F.; Kovarova, J.; Cunha-Oliveira, T.; Neuzil, J.; Pountney, D.L. Intracellular and Intercellular Mitochondrial Dynamics in Parkinson's Disease. Front. Neurosci. 2019, 13, 930. [CrossRef]

141. Garofano, L.; Migliozzi, S.; Oh, Y.T.; D’Angelo, F.; Najac, R.D.; Ko, A.; Frangaj, B.; Caruso, F.P.; Yu, K.; Yuan, J.; et al. PathwayBased Classification of Glioblastoma Uncovers a Mitochondrial Subtype with Therapeutic Vulnerabilities. Nat. Cancer 2021, 2, 141-156. [CrossRef]

142. Kim, H.J.; Park, J.W.; Lee, J.H. Genetic Architectures and Cell-of-Origin in Glioblastoma. Front. Oncol. 2021, 10, 3097. [CrossRef] [PubMed]

143. Neftel, C.; Laffy, J.; Filbin, M.G.; Hara, T.; Shore, M.E.; Rahme, G.J.; Richman, A.R.; Silverbush, D.; Shaw, M.L.; Hebert, C.M.; et al. An Integrative Model of Cellular States, Plasticity, and Genetics for Glioblastoma. Cell 2019, 178, 835-849.e21. [CrossRef]

144. Vieira de Castro, J.; Gonçalves, C.S.; Hormigo, A.; Costa, B.M. Exploiting the Complexities of Glioblastoma Stem Cells: Insights for Cancer Initiation and Therapeutic Targeting. Int. J. Mol. Sci. 2020, 21, 5278. [CrossRef]

145. Wang, L.-B.; Karpova, A.; Gritsenko, M.A.; Kyle, J.E.; Cao, S.; Li, Y.; Rykunov, D.; Colaprico, A.; Rothstein, J.H.; Hong, R.; et al. Proteogenomic and Metabolomic Characterization of Human Glioblastoma. Cancer Cell 2021, 39, 509-528.e20. [CrossRef]

146. Yabo, Y.A.; Niclou, S.P.; Golebiewska, A. Cancer Cell Heterogeneity and Plasticity: A Paradigm Shift in Glioblastoma. NeuroOncology 2021. (online ahead of print). [CrossRef] [PubMed]

147. Osuka, S.; Van Meir, E.G. Overcoming Therapeutic Resistance in Glioblastoma: The Way Forward. J. Clin. Investig. 2017, 127, 415-426. [CrossRef] [PubMed]

148. Xie, X.P.; Laks, D.R.; Sun, D.; Ganbold, M.; Wang, Z.; Pedraza, A.M.; Bale, T.; Tabar, V.; Brennan, C.; Zhou, X.; et al. Quiescent Human Glioblastoma Cancer Stem Cells Drive Tumor Initiation, Expansion, and Recurrence Following Chemotherapy. Dev. Cell 2022, 57, 32-46.e8. [CrossRef]

149. Prager, B.C.; Bhargava, S.; Mahadev, V.; Hubert, C.G.; Rich, J.N. Glioblastoma Stem Cells: Driving Resilience through Chaos. Trends Cancer 2020, 6, 223-235. [CrossRef]

150. Hitomi, M.; Chumakova, A.P.; Silver, D.J.; Knudsen, A.M.; Pontius, W.D.; Murphy, S.; Anand, N.; Kristensen, B.W.; Lathia, J.D. Asymmetric Cell Division Promotes Therapeutic Resistance in Glioblastoma Stem Cells. JCI Insight 2021, 6, 130510. [CrossRef]

151. Almairac, F.; Turchi, L.; Sakakini, N.; Debruyne, D.N.; Elkeurti, S.; Gjernes, E.; Polo, B.; Bianchini, L.; Fontaine, D.; Paquis, P.; et al. ERK-Mediated Loss of MiR-199a-3p and Induction of EGR1 Act as a "Toggle Switch" of GBM Cell Dedifferentiation into NANOGand OCT4-Positive Cells. Cancer Res. 2020, 80, 3236-3250. [CrossRef]

152. Gao, X.; Zhang, Z.; Mashimo, T.; Shen, B.; Nyagilo, J.; Wang, H.; Wang, Y.; Liu, Z.; Mulgaonkar, A.; Hu, X.-L.; et al. Gliomas Interact with Non-Glioma Brain Cells via Extracellular Vesicles. Cell Rep. 2020, 30, 2489-2500.e5. [CrossRef]

153. Guelfi, S.; Orsetti, B.; Deleuze, V.; Rigau, V.; Bauchet, L.; Duffau, H.; Rothhut, B.; Hugnot, J.-P. SLUG and Truncated TAL1 Reduce Glioblastoma Stem Cell Growth Downstream of Notch1 and Define Distinct Vascular Subpopulations in Glioblastoma Multiforme. Cancers 2021, 13, 5393. [CrossRef]

154. Monje, M.; Borniger, J.C.; D’Silva, N.J.; Deneen, B.; Dirks, P.B.; Fattahi, F.; Frenette, P.S.; Garzia, L.; Gutmann, D.H.; Hanahan, D.; et al. Roadmap for the Emerging Field of Cancer Neuroscience. Cell 2020, 181, 219-222. [CrossRef]

155. Valdebenito, S.; Malik, S.; Luu, R.; Loudig, O.; Mitchell, M.; Okafo, G.; Bhat, K.; Prideaux, B.; Eugenin, E.A. Tunneling Nanotubes, TNT, Communicate Glioblastoma with Surrounding Non-Tumor Astrocytes to Adapt Them to Hypoxic and Metabolic Tumor Conditions. Sci. Rep. 2021, 11, 14556. [CrossRef]

156. Formicola, B.; D'Aloia, A.; Dal Magro, R.; Stucchi, S.; Rigolio, R.; Ceriani, M.; Re, F. Differential Exchange of Multifunctional Liposomes Between Glioblastoma Cells and Healthy Astrocytes via Tunneling Nanotubes. Front. Bioeng. Biotechnol. 2019, 7, 403. [CrossRef] 
157. English, K.; Shepherd, A.; Uzor, N.-E.; Trinh, R.; Kavelaars, A.; Heijnen, C.J. Astrocytes Rescue Neuronal Health after Cisplatin Treatment through Mitochondrial Transfer. Acta Neuropathol. Commun. 2020, 8, 36. [CrossRef]

158. Caicedo, A.; Fritz, V.; Brondello, J.-M.; Ayala, M.; Dennemont, I.; Abdellaoui, N.; de Fraipont, F.; Moisan, A.; Prouteau, C.A.; Boukhaddaoui, H.; et al. MitoCeption as a New Tool to Assess the Effects of Mesenchymal Stem/Stromal Cell Mitochondria on Cancer Cell Metabolism and Function. Sci. Rep. 2015, 5, 9073. [CrossRef]

159. Nakhle, J.; Özkan, T.; Lněničková, K.; Briolotti, P.; Vignais, M.-L. Methods for Simultaneous and Quantitative Isolation of Mitochondrial DNA, Nuclear DNA and RNA from Mammalian Cells. Biotechniques 2020, 69, 436-442. [CrossRef]

160. Nzigou Mombo, B.; Gerbal-Chaloin, S.; Bokus, A.; Daujat-Chavanieu, M.; Jorgensen, C.; Hugnot, J.-P.; Vignais, M.-L. MitoCeption: Transferring Isolated Human MSC Mitochondria to Glioblastoma Stem Cells. J. Vis. Exp. 2017, 120, e55245. [CrossRef] 